\title{
Increased carbon capture by a silicate-treated forested watershed affected by acid deposition
}

\author{
Lyla L. Taylor ${ }^{1}$, Charles T. Driscoll ${ }^{2}$, Peter M. Groffman ${ }^{3,4}$, Greg H. Rau ${ }^{5}$, Joel D. Blum ${ }^{6}$, and David J. Beerling ${ }^{1}$ \\ ${ }^{1}$ Leverhulme Centre for Climate Change Mitigation, Department of Animal and Plant Sciences, \\ University of Sheffield, Sheffield S10 2TN, UK \\ ${ }^{2}$ Department of Civil and Environmental Engineering, 151 Link Hall, Syracuse University, Syracuse, NY 13244, USA \\ ${ }^{3}$ City University of New York, Advanced Science Research Center at the Graduate Center, New York, NY 10031, USA \\ ${ }^{4}$ Cary Institute of Ecosystem Studies, Millbrook, NY 12545, USA \\ ${ }^{5}$ Institute of Marine Sciences, University of California, Santa Cruz, CA 95064, USA \\ ${ }^{6}$ Department of Earth and Environmental Sciences, University of Michigan, Ann Arbor, MI 48109, USA
}

Correspondence: Lyla L. Taylor (1.1.taylor@sheffield.ac.uk)

Received: 23 July 2020 - Discussion started: 31 July 2020

Revised: 8 November 2020 - Accepted: 13 November 2020 - Published: 12 January 2021

\begin{abstract}
Meeting internationally agreed-upon climate targets requires carbon dioxide removal (CDR) strategies coupled with an urgent phase-down of fossil fuel emissions. However, the efficacy and wider impacts of CDR are poorly understood. Enhanced rock weathering (ERW) is a land-based CDR strategy requiring large-scale field trials. Here we show that a low $3.44 \mathrm{tha}^{-1}$ wollastonite treatment in an 11.8 ha acid-rain-impacted forested watershed in New Hampshire, USA, led to cumulative carbon capture by carbonic acid weathering of $0.025-0.13 \mathrm{tCO}_{2} \mathrm{ha}^{-1}$ over 15 years. Despite a $0.8-2.4 \mathrm{t} \mathrm{CO}_{2} \mathrm{ha}^{-1}$ logistical carbon penalty from mining, grinding, transportation, and spreading, by 2015 weathering together with increased forest productivity led to net CDR of 8.5-11.5 $\mathrm{tCO}_{2} \mathrm{ha}^{-1}$. Our results demonstrate that ERW may be an effective, scalable CDR strategy for acid-impacted forests but at large scales requires sustainable sources of silicate rock dust.
\end{abstract}

\section{Introduction}

The Intergovernmental Panel on Climate Change (IPCC) (Rogelj et al., 2018) Special Report on global warming indicates large-scale deployment of carbon dioxide removal (CDR) technologies will be required to avoid warming in excess of $1.5^{\circ} \mathrm{C}$ by the end of this century. Land-based CDR strategies include enhanced rock weathering (ERW), which aims to accelerate the natural geological process of carbon sequestration by amending soils with crushed reactive calcium (Ca)- and magnesium $(\mathrm{Mg})$-bearing rocks such as basalt (The Royal Society and The Royal Academy of Engineering, 2018; Hartmann et al., 2013). Forests represent potential large-scale deployment opportunities where rock amendments may provide a range of benefits, including amelioration of soil acidification and provisioning of inorganic plant nutrients to cation-depleted soils (Hartmann et al., 2013; Beerling et al., 2018). Although ERW has not yet been demonstrated as a CDR technique at the catchment scale, a forested watershed experiment at the Hubbard Brook Experimental Forest (HBEF, $43^{\circ} 56^{\prime} \mathrm{N}, 71^{\circ} 45^{\prime} \mathrm{W}$ ) in the White Mountains of New Hampshire, USA, provides an unusual opportunity for assessing proof of concept in this priority research area.

The HBEF watershed experiment, designed to restore soil calcium following decades of leaching by acid rain, involved application of a finely ground rapidly weathered calcium silicate mineral wollastonite $\left(\mathrm{CaSiO}_{3} ; 3.44 \mathrm{tha}^{-1}\right)$ on $19 \mathrm{Oc}$ tober 1999 to an 11.8 ha forested watershed (Likens et al., 2004; Peters et al., 2004; Shao et al., 2016). Unlike the carbonate minerals (e.g. $\mathrm{CaCO}_{3}$ ) commonly applied to acidified soils (Lundström et al., 2003), wollastonite does not release $\mathrm{CO}_{2}$ when weathered (Supplement) so is much better suited for CDR (Hartmann et al., 2013). It also has dissolution kinetics comparable to or faster than other calcium-rich sili- 
cate minerals such as labradorite found in basalt (Brantley et al., 2008). Thus, the HBEF experiment provides a timely and unparalleled opportunity for investigating the long-term (15 years) effects of ERW on CDR potential via forest and stream-water chemistry responses.

In the case of ERW with wollastonite, CDR follows as $\mathrm{Ca}$ cations $\left(\mathrm{Ca}^{2+}\right)$ liberated by weathering consume atmospheric $\mathrm{CO}_{2}$ through the formation of bicarbonate $\left(\mathrm{HCO}_{3}^{-}\right)$by charge balance, as described by the following reaction:

$\mathrm{CaSiO}_{3}+3 \mathrm{H}_{2} \mathrm{O}+2 \mathrm{CO}_{2} \rightarrow \mathrm{Ca}^{2+}+\mathrm{H}_{4} \mathrm{SiO}_{4}+2 \mathrm{HCO}_{3}^{-}$.

However, forests in the northeastern USA have experienced acid deposition (Likens and Bailey, 2014), changes in nitrogen cycling (Goodale and Aber, 2001; McLauchlan et al., 2007), and increases in dissolved organic carbon (DOC) fluxes (Cawley et al., 2014) that may affect $\mathrm{CO}_{2}$ removal efficiency by ERW processes. In particular, $\mathrm{CO}_{2}$ consumption as measured by bicarbonate production may be diminished if sulfate $\left(\mathrm{SO}_{4}^{2-}\right)$, nitrate $\left(\mathrm{NO}_{3}^{-}\right)$, or naturally occurring organic acid (OA) anions (Fakhraei and Driscoll, 2015) $\left(\mathrm{H}_{2} \mathrm{~A}^{-}\right)$in DOC intervene to inhibit the following mineral weathering reactions. For example

$$
\begin{aligned}
& \mathrm{CaSiO}_{3}+\mathrm{H}_{2} \mathrm{O}+\mathrm{H}_{2} \mathrm{SO}_{4} \rightarrow \mathrm{Ca}^{2+}+\mathrm{H}_{4} \mathrm{SiO}_{4}+\mathrm{SO}_{4}^{2-}, \\
& \mathrm{CaSiO}_{3}+\mathrm{H}_{2} \mathrm{O}+2 \mathrm{HNO}_{3} \rightarrow \mathrm{Ca}^{2+}+\mathrm{H}_{4} \mathrm{SiO}_{4}+2 \mathrm{NO}_{3}^{-}, \\
& \mathrm{CaSiO}_{3}+\mathrm{H}_{2} \mathrm{O}+2 \mathrm{H}_{3} \mathrm{~A} \rightarrow \mathrm{Ca}^{2+}+\mathrm{H}_{4} \mathrm{SiO}_{4}+2 \mathrm{H}_{2} \mathrm{~A}^{-} .
\end{aligned}
$$

These environmental effects on stream-water chemistry are well documented at the HBEF (Cawley et al., 2014; Likens and Bailey, 2014; Rosi-Marshall et al., 2016; McLauchlan et al., 2007) and may be exacerbated under future climate change (Sebestyen et al., 2009; Campbell et al., 2009).

Here we exploit the experimental design and long-term monitoring of stream-water chemistry, trees, and soils for two small forested HBEF watersheds to evaluate the effects of the wollastonite treatment in 1999 on catchment $\mathrm{CO}_{2}$ consumption via inorganic and organic pathways. Further, we examine how biogeochemical perturbations in $\mathrm{S}, \mathrm{N}$, and organic carbon cycling affect catchment inorganic $\mathrm{CO}_{2}$ consumption. We consider the forest response, the carbon cost for ERW deployment (mining, grinding, transportation, and application), and the net greenhouse gas balance for the treatment. Finally, we provide an initial assessment of the net CDR potential of silicate treatments deployed over larger areas of acidified forest in the northeastern United States.

\section{Methods}

This section describes the site and wollastonite treatment (Sect. 2.1) and our approaches for modelling the inorganic carbon fluxes in stream water (Sect. 2.2) and other greenhouse gas fluxes associated with the treatment (Sect. 2.3). The variables from each of the seven equations in Methods are tabulated in Table 1 along with the section, equation, figure, and table numbers where they appear.

\subsection{Site and treatment}

\subsubsection{Site description}

The HBEF has a temperate climate with $\sim 1400 \mathrm{~mm}$ mean annual precipitation of which up to one-third falls as snow (Campbell et al., 2007). The mean temperatures in January and July are -9 and $18^{\circ} \mathrm{C}$ respectively, and the period from mid-May to mid-September comprises the growing season (Campbell et al., 2007). There are six small southeast-facing watersheds in the HBEF (Fig. 1) with 20\%-30\% slopes (Groffman et al., 2006), including one which received the silicate treatment (watershed W1, 11.8 ha, 488-747 m a.s.l.) and a biogeochemical reference (watershed W6, 13.2 ha, 545-791 ma.s.1.). Carbonate and evaporite minerals are in very low abundance $(<1 \%$ calcite in the crystalline rocks and glacial deposits) in these silicate-mineral-dominated watersheds (Johnson et al., 1981). Well-drained Typic Haplorthod soils with $\mathrm{pH}<4.5$ and mean depth of $0.6 \mathrm{~m}$ formed from relatively impermeable glacial till, which restricts water flow and protects the underlying schist bedrock from weathering. Overland runoff and flow through bedrock are both thought to be negligible (Likens, 2013). Hydrologically, the HBEF watersheds are typical of small catchments in northern New England (Sopper and Lull, 1965). Flow rates for $\mathrm{W} 1$ and $\mathrm{W} 6$ along with stream-water $\mathrm{pH}$ are shown in Fig. S1 in the Supplement. Prior to treatment, stream-water calcium concentrations were under $30 \mu \mathrm{mol} \mathrm{L}^{-1}$ while bicarbonate concentrations were under $5 \mu \mathrm{mol} \mathrm{L}{ }^{-1}$, below the ranges for typical world rivers (Moon et al., 2014) (60$2293 \mu \mathrm{mol} \mathrm{Ca}{ }^{2+} \mathrm{L}^{-1}, 179-4926 \mu \mathrm{mol} \mathrm{HCO}_{3}^{-} \mathrm{L}^{-1}$ ).

Fagus grandifolia Britt., Betula alleghaniensis Ehrh., and Acer saccharum Marsh. are the dominant trees in this northern hardwood forest, while Betula papyrifera Marsh., Abies balsamea (L.) Mill., and Picea rubens Sarq. are common at the highest elevations where soils tend to be shallow and wetter (Cho et al., 2012). A. saccharum and P. rubens are both calcium-sensitive, but soil calcium-bearing minerals are less available to A. saccharum (Blum et al., 2002), and total bioavailable calcium content decreases with elevation (Cho et al., 2012). This silicate-addition experiment was designed to replace bioavailable calcium which had been stripped from the soils by decades of acid deposition.

\subsubsection{Treatment description}

On 19 and 21 October 1999, W1 was treated with $344 \mathrm{~g} \mathrm{~m}^{-2}$ of pelletized wollastonite $\left(\mathrm{CaSiO}_{3}\right)$ by a GPS-equipped helicopter with a motorized spreader to ensure even deployment across the catchment, including the $1804 \mathrm{~m}^{2}$ streambed (Peters et al., 2004). Following treatment, the lignin-sulfonate binder forming the pellets dissolved within several days (Peters et al., 2004), and the ground wollastonite itself dissolved rapidly in the upper Oie soil horizon, increasing Oie base saturation from $40 \%$ to $78 \%$ and raising soil $\mathrm{pH}$ from 3.88 to 
Table 1. Summary of variables presented in Methods (Sect. 2, Eqs. 1 through 7).

\begin{tabular}{|c|c|c|c|c|c|c|}
\hline Variable & Units & Sections & Equations & Figures & Tables & Description \\
\hline$\left[\mathrm{HCO}_{3}^{-}\right]$ & $\mathrm{mol} \mathrm{kgw}^{-1}$ & $2.2 .3,2.2 .4$ & (1), (3) & $\begin{array}{l}\text { 2a, S5a, d, } \\
\text { g, S6a }\end{array}$ & & $\begin{array}{l}\text { Concentrations of solutes in water, in this case } \\
\mathrm{HCO}_{3}^{-} \text {, are denoted by square brackets. }\end{array}$ \\
\hline$t$ & time & $2.2 .3-5$ & $1-5$ & & & Denotes individual samples in the time series \\
\hline$\alpha_{\text {rain }, \mathrm{HCO}_{3}}$ & fraction & $\begin{array}{l}2.2 .3,2.2 .4 \\
\text { Appendix A }\end{array}$ & $\begin{array}{l}(1),(2) \\
(\mathrm{A} 2)\end{array}$ & S3 & & $\begin{array}{l}\text { Fraction of an ion, in this case } \mathrm{HCO}_{3}^{-} \text {, originat- } \\
\text { ing from precipitation. }\end{array}$ \\
\hline flow & $\mathrm{mm} \mathrm{yr}^{-1}$ & $2.2 .3-5$ & (1)-(5) & $\mathrm{S} 2 \mathrm{~d}$ & & Stream-water flow \\
\hline $\mathrm{CO}_{2, \mathrm{HCO}_{3}}$ & ${\mathrm{molC} \mathrm{yr}^{-1}}^{-1}$ & $2.2 .3,2.2 .4$ & $(1),(3)$ & $\begin{array}{l}2 b, S 5 b, e, \\
h\end{array}$ & $3, \mathrm{~S} 1$ & $\begin{array}{l}\text { Total watershed } \mathrm{CO}_{2} \text { consumption as calculated } \\
\text { from bicarbonate }\end{array}$ \\
\hline $\mathrm{CO}_{2, \text { ions }}$ & ${\operatorname{molC~} \mathrm{yr}^{-1}}^{-1}$ & 2.2 .3 & (2) & & 3 & $\begin{array}{l}\text { Total watershed } \mathrm{CO}_{2} \text { consumption as calculated } \\
\text { from major ions }\end{array}$ \\
\hline Wo- $\mathrm{CO}_{2}, \mathrm{HCO}_{3}$ & ${\mathrm{molC} \mathrm{yr}^{-1}}^{-1}$ & 2.2 .4 & (3) & $\begin{array}{l}2 c, 5, S 5 c \\
f, i, S 6 b, c\end{array}$ & $3,4, \mathrm{~S} 1$ & $\begin{array}{l}\text { Watershed } \mathrm{CO}_{2} \text { consumption as calculated } \\
\text { from bicarbonate resulting from wollastonite } \\
\text { weathering. Our conservative/pessimistic } \\
\Delta \text { CONS estimate in our GHG balance is the } \\
15 \text {-year sum. }\end{array}$ \\
\hline$X_{\mathrm{Ca}}$ & fraction & $\begin{array}{l}\text { 2.2.3, } \\
\text { Appendix B }\end{array}$ & $\begin{array}{l}(3),(4) \\
(\mathrm{B} 1)\end{array}$ & S1a & & $\begin{array}{l}\text { Fraction of total calcium originating from wol- } \\
\text { lastonite }\end{array}$ \\
\hline Wo- $\mathrm{CO}_{2, \mathrm{Ca}}$ & ${\operatorname{molC~} \mathrm{yr}^{-1}}^{-1}$ & 2.2 .3 & (4) & $2 f, S 6 b, c$ & $3, \mathrm{~S} 1$ & $\begin{array}{l}\text { Watershed } \mathrm{CO}_{2} \text { consumption as calculated } \\
\text { from calcium due to wollastonite weathering. } \\
\text { Our optimistic estimate for } \triangle \mathrm{CONS} \text { in our } \\
\text { GHG balance is the } 15 \text {-year sum. }\end{array}$ \\
\hline$C_{i}$ & $\mathrm{~mol} \mathrm{kgw}^{-1}$ & 2.2 .5 & (5) & & & $\begin{array}{l}\text { Concentration of solute for sample } i \text { (collected } \\
\text { approximately monthly for chemical analysis) }\end{array}$ \\
\hline$Q_{i}$ & mm time ti $^{-1}$ & 2.2 .5 & (5) & & & Streamflow for sample $i$ \\
\hline$Q_{k}$ & $\mathrm{~mm} \mathrm{~d}^{-1}$ & 2.2 .5 & (5) & $\mathrm{S} 2 \mathrm{~b}$ & & Streamflow for day $k$ \\
\hline$N$ & number & 2.2 .5 & (5) & & & Number of daily flow measurements \\
\hline$\Delta \mathrm{GHG}$ & $\mathrm{tCO}_{2} \mathrm{ha}^{-1}$ & 2.3 .1 & (6) & 5 & 4 & $\begin{array}{l}\text { Net treatment effect on watershed greenhouse } \\
\text { gas balance }\end{array}$ \\
\hline$\Delta$ wood & $\mathrm{tCO}_{2} \mathrm{ha}^{-1}$ & 2.3 .1 & (6) & 5 & 4 & $\begin{array}{l}\text { Treatment effect on woody biomass over } 10 \\
\text { years: positive if wood production increases rel- } \\
\text { ative to reference watershed. }\end{array}$ \\
\hline$\Delta \mathrm{CH} 4$ & $\mathrm{tCO}_{2} \mathrm{ha}^{-1}$ & 2.3 .1 & (6) & 5 & 4 & $\begin{array}{l}\text { Treatment effect on soil } \mathrm{CH}_{4} \text { sink since } 2002 \text { : } \\
\text { positive if the soil } \mathrm{CH}_{4} \text { sink increases relative } \\
\text { to reference watershed. }\end{array}$ \\
\hline$\triangle$ SRESP & $\mathrm{tCO}_{2} \mathrm{ha}^{-1}$ & 2.3 .1 & (6) & 5 & 4 & $\begin{array}{l}\text { Treatment effect on soil } \mathrm{CO}_{2} \text { emissions since } \\
\text { 2002: positive if emissions decrease relative to } \\
\text { reference watershed. }\end{array}$ \\
\hline$\triangle \mathrm{CONS}$ & $\mathrm{tCO}_{2} \mathrm{ha}^{-1}$ & 2.3 .1 & (6) & 5 & 4 & $\begin{array}{l}\text { Treatment effect on } \mathrm{CO}_{2} \text { consumption over } \\
15 \text { years: ranges from } \mathrm{Wo}-\mathrm{CO}_{2, \mathrm{HCO}_{3}} \text { to Wo- } \\
\mathrm{CO}_{2, \mathrm{Ca}}\end{array}$ \\
\hline$\Delta \mathrm{N} 2 \mathrm{O}$ & $\mathrm{tCO}_{2} \mathrm{ha}^{-1}$ & 2.3 .1 & (6) & 5 & 4 & $\begin{array}{l}\text { Treatment effect on soil } \mathrm{N}_{2} \mathrm{O} \text { emissions since } \\
\text { 2002: positive if emissions decrease relative to } \\
\text { reference watershed. }\end{array}$ \\
\hline
\end{tabular}


Table 1. Continued.

\begin{tabular}{|c|c|c|c|c|c|c|}
\hline Variable & Units & Sections & Equations & Figures & Tables & Description \\
\hline$\Delta \mathrm{NO} 3 \mathrm{~N} 2 \mathrm{O}$ & $\mathrm{tCO}_{2} \mathrm{ha}^{-1}$ & 2.3 .1 & (6) & 5 & 4 & $\begin{array}{l}\text { Treatment effect on downstream } \mathrm{N}_{2} \mathrm{O} \text { emis- } \\
\text { sions (due to nitrate export) over } 15 \text { years: pos- } \\
\text { itive if emissions decrease relative to reference } \\
\text { watershed. }\end{array}$ \\
\hline$\triangle \mathrm{DOC}$ & $\mathrm{tCO}_{2} \mathrm{ha}^{-1}$ & 2.3 .1 & (6) & 5 & 4 & $\begin{array}{l}\text { Treatment effect on dissolved organic carbon } \\
\text { export over } 15 \text { years: positive if export de- } \\
\text { creases relative to reference watershed. This } \\
\text { represents carbon loss from the watershed and } \\
\text { likely } \mathrm{CO}_{2} \text { emissions downstream. }\end{array}$ \\
\hline LOGPEN & $\mathrm{tCO}_{2} \mathrm{ha}^{-1}$ & 2.3 .1 & (6) & 5 & 4 & $\begin{array}{l}\text { Logistical emissions penalty associated with } \\
\text { mining, milling, pelletization, transport, and ap- } \\
\text { plication of the wollastonite treatment, expected } \\
\text { to be negative. }\end{array}$ \\
\hline$s$ & $\mathrm{~m}^{2} \mathrm{~kg}^{-1}$ & 2.3 .3 & (7) & & & Specific surface area of material being milled \\
\hline$e_{\mathrm{p}}$ & $\mathrm{kJ} \mathrm{kg}^{-1}$ & 2.3 .3 & (7) & & & $\begin{array}{l}\text { Specific potential energy of material being } \\
\text { milled }\end{array}$ \\
\hline
\end{tabular}

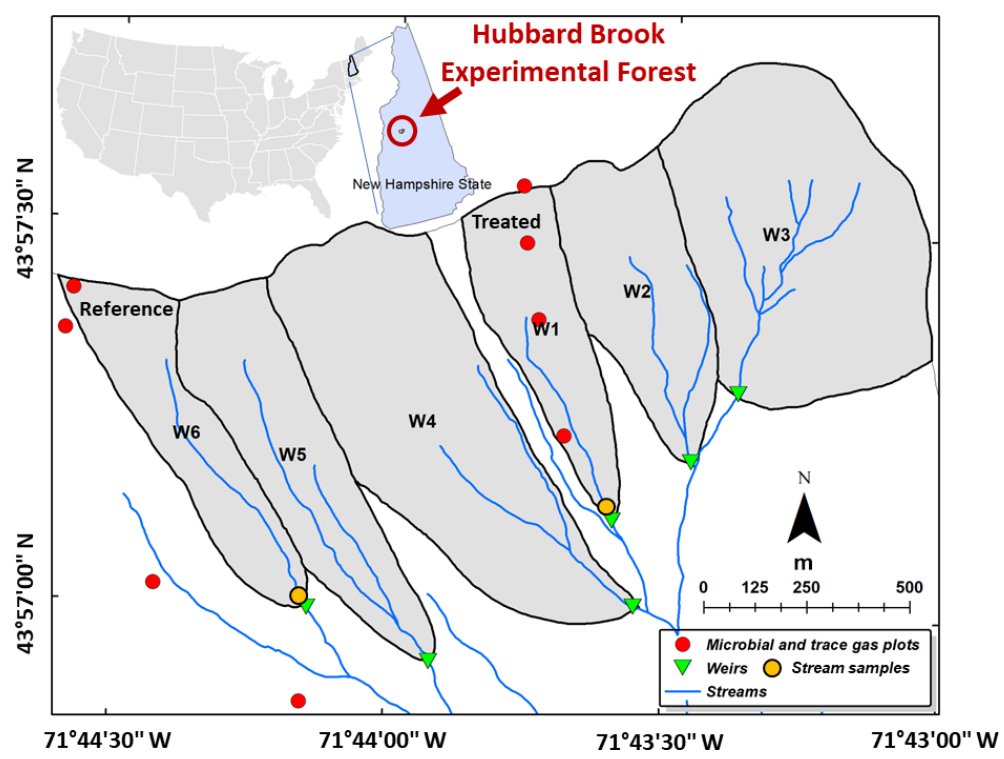

Figure 1. Location of the sampling sites and experimental watersheds. Our stream-water samples were collected just upstream of the weirs in the treated and reference watersheds (gold discs), and our trace gas samples were collected at different elevations in treated (W1) and untreated (W6) forests (red discs).

4.39 within 1 year (Johnson et al., 2014). Although the budget of wollastonite-derived calcium (Wo-Ca) has never been closed due to lack of data from vegetation and from deeper soil layers (Shao et al., 2016), it is thought that uptake by vegetation and retention by soil exchange sites delayed transport of Wo-Ca to lower soil horizons and stream water for 3 years (Johnson et al., 2014).

\subsection{Geochemical modelling and $\mathrm{CO}_{2}$ consumption fluxes}

$\mathrm{CO}_{2}$ consumption, the $\mathrm{CDR}$ pathway most closely associated with ERW, can be calculated from concentrations of either bicarbonate or the base cations released during weathering (Reaction R1). These two approaches may provide different answers if bicarbonate is reduced in the presence of other acids (Reactions R2-R4). To calculate bicarbonate-derived $\mathrm{CO}_{2}$ consumption, we must model the speciation of dis- 
solved inorganic carbon (DIC). This depends on two variables which must also be modelled because we do not have a time series: stream-water $p \mathrm{CO}_{2}$ and stream-water temperature. We then calculate total catchment $\mathrm{CO}_{2}$ consumption fluxes and treatment effects, taking care to account for differences in sampling frequency between chemistry samples and water flow measurements.

\subsubsection{Forward modelling of stream-water chemistry including dissolved inorganic carbon}

We used a forward modelling approach to calculate dissolved stream-water bicarbonate concentrations $\left(\left[\mathrm{HCO}_{3}^{-}\right]_{\text {stream }}\right)$ in the treated and reference watersheds (Fig. 1) over $\sim 25$ years, including 15 years post-treatment, with the United States Geological Survey (USGS) aqueous geochemistry software PHREEQC version 3.3.12-12704 (Parkhurst and Appelo, 1999) and monthly long-term (1992-2014) stream-water (Driscoll, 2016b, a) and rain and snow precipitation (Likens, 2016b, a) chemistry measurements.

Using MATLAB (version R2016a) scripts, we wrote PHREEQC input files and determined the inorganic carbon species for each stream-water sample with PHREEQC. Along with a standard database which decouples ammonium and nitrate (Amm.dat, provided with the PHREEQC software), we included the ionization constants for the organic acid triprotic analogue and the constants for $\mathrm{Al} \mathrm{com-}$ plexation described for Hubbard Brook streams (Fakhraei and Driscoll, 2015) in our PHREEQC simulations. These are $\mathrm{pK}_{a 1}=2.02, \mathrm{pK}_{a 2}=6.63, \mathrm{pK}_{a 3}=7.30, \mathrm{pK}_{\mathrm{Al} 1}=4.07$, $\mathrm{pK}_{\mathrm{Al} 2}=7.37, \mathrm{pK}_{\mathrm{Al} 3}=6.65$, and site density $m=0.064 \mathrm{~mol}$ sites $\mathrm{mol} \mathrm{C}^{-1}$. Our organic acid concentrations are the product of the corresponding site density of reactions and the measured dissolved organic carbon concentration (Fakhraei and Driscoll, 2015); these were PHREEQC inputs along with total monomeric $\mathrm{Al}$ and major ion concentrations from the longitudinal datasets.

Spectator ions $\left(\mathrm{Cl}^{-}\right.$and $\left.\mathrm{NH}_{4}^{+}\right)$were adjusted to achieve charge balance given the measured $\mathrm{pH}$ for the treated and reference watersheds. $\mathrm{Cl}^{-}$was only adjusted when charge balance was not achieved using $\mathrm{NH}_{4}^{+}$alone. This was deemed to be the case when PHREEQC failed to converge or when the percent error exceeded $5 \%$. We used original rather than adjusted rainwater $\mathrm{Cl}$ to calculate the contribution of rainwater to stream-water chemistry (described below). These adjusted ions were then held constant for our modelled scenarios, while $\mathrm{pH}$ was allowed to vary.

Exploratory PHREEQC tests (charge balancing on DIC) either with or without organic acids suggest that the acids depress total DIC, $\mathrm{HCO}_{3}^{-}$, and also the saturation state of gaseous $\mathrm{CO}_{2}$. Similar variability in the saturation is also observed when DIC values from partially degassed samples from the streams are used as input. We chose minimum and maximum values of 1100 and $1700 \mathrm{ppm}$, or $\sim 3$ and $4.6 \times 368$, the mean value of Mauna Loa $p \mathrm{CO}_{2}$ (Tans and Keeling, 2017) for 1985-2012. These values correspond to $\log _{10}\left(p \mathrm{CO}_{2}(\mathrm{~g})\right)=-2.87 \pm 0.09 \mathrm{SD}$ derived from a prior analysis of this variability for the same time range (Fakhraei and Driscoll, 2015).

\subsubsection{Stream-water temperature}

Air temperatures for the Hubbard Brook watersheds (Campbell, 2016) were converted to stream-water temperatures (Mohseni and Stefan, 1999). Rainwater temperatures were set equal to stream-water temperatures. These temperatures were used in our PHREEQC modelling, with equilibrium constants for the DIC species as functions of temperature. Only samples measured closest to the weirs and with a valid $\mathrm{pH}$ were processed with PHREEQC.

\subsubsection{Total catchment $\mathrm{CO}_{2}$ consumption}

We calculate total annual watershed $\mathrm{CO}_{2}$ consumption (Reaction R1) as the product of stream-water flow and streamwater bicarbonate concentration $\left[\mathrm{HCO}_{3}^{-}\right]$at time $t$ corrected for the $\mathrm{HCO}_{3}^{-}$contribution from rainwater $\left(\alpha_{\text {rain, } \mathrm{HCO} 3}(t)\right.$, Appendix A):

$\mathrm{CO}_{2, \mathrm{HCO}_{3}}(t)=\left(1-\alpha_{\mathrm{rain}, \mathrm{HCO}_{3}}(t)\right)\left[\mathrm{HCO}_{3}^{-}\right](t) \times$ flow $(t)$,

where $\left[\mathrm{HCO}_{3}^{-}\right](t)$ is given in $\mathrm{mol} \mathrm{kgw}^{-1}$ and flow $(t)$ is the "runoff" in $\mathrm{mm} \mathrm{yr}^{-1}$. Calculated $\left[\mathrm{HCO}_{3}^{-}\right]$and annual $\mathrm{CO}_{2}$ consumption for the treated and reference watersheds (Eq. 1) comprise our baseline simulations and represent a primary test of hypothesized increased carbon capture resulting from weathering of the applied silicate.

Bicarbonate-derived $\mathrm{CO}_{2}$ consumption (Eq. 1) is the most conservative approach to estimating net carbon fluxes related to ERW. For natural freshwaters in equilibrium with the atmosphere, this entails a titration for total alkalinity with a possible correction for the concentration of organic acid anions (Köhler et al., 2000). However, another widely used (Jacobson and Blum, 2003) measure of $\mathrm{CO}_{2}$ consumption is derived by assuming that any base cations $\left(\mathrm{Ca}^{2+}, \mathrm{Mg}^{2+}, \mathrm{K}^{+}\right.$, and $\mathrm{Na}^{+}$) released from minerals will be charge-balanced by bicarbonate formation in the oceans:

$$
\begin{aligned}
\mathrm{CO}_{2, \text { ions }}(t) & =\left(2\left[\mathrm{Ca}^{2+}\right]\left(1-\alpha_{\text {rain, } \mathrm{Ca}}(t)\right)\right. \\
& +2\left[\mathrm{Mg}^{2+}\right]\left(1-\alpha_{\text {rain, } \mathrm{Mg}}(t)\right) \\
& +\left[\mathrm{K}^{+}\right]\left(1-\alpha_{\text {rain, } \mathrm{K}}(t)\right) \\
& \left.+\left[\mathrm{Na}^{+}\right]\left(1-\alpha_{\text {rain, } \mathrm{Na}}(t)\right)-2\left[\mathrm{SO}_{4}^{2-}\right](t)\right) \\
& \times \text { flow }(t),
\end{aligned}
$$

where the term $-2\left[\mathrm{SO}_{4}^{2-}\right](t)$ represents a commonly applied correction for sulfuric acid weathering (Chetelat et al., 2008) (Reaction R2). Contributions from precipitation such as $\alpha_{\text {rain, } \mathrm{Ca}}(t)$ are calculated by replacing bicarbonate with the individual base cation in Eq. (A2). We tabulate $\mathrm{CO}_{2 \text {,ions }}(t)$ results for comparison with $\mathrm{CO}_{2, \mathrm{HCO}_{3}}(t)$ below. 


\subsubsection{Response of $\mathrm{CO}_{2}$ consumption to treatment}

To isolate a treatment effect for bicarbonate, we used strontium isotopes as a tracer of wollastonite (Wo) weathering within a previously published mixing function (Nezat et al., 2010; Peters et al., 2004) (Appendix B, Fig. S3). This mixing function provides the fraction $X_{\mathrm{Ca}}$ of calcium originating from wollastonite (Eq. B1). We remove the contribution of all mineral sources other than wollastonite to $\mathrm{CO}_{2}$ consumption (Eq. 1), which is simulated with $\mathrm{Ca}^{2+}$ concentrations reduced by $\left(1-X_{\mathrm{Ca}}\right)$ :

$$
\begin{aligned}
\text { Wo- } \mathrm{CO}_{2, \mathrm{HCO}_{3}}(t) & =\mathrm{CO}_{2, \mathrm{HCO}_{3}}(t) \\
& -\left\{\left[\mathrm{HCO}_{3}^{-}\right]\left(t,\left(1-X_{\mathrm{Ca}}\right)\left[\mathrm{Ca}^{2+}\right]\right)\right. \\
& \left.\times\left(1-\alpha_{\text {rain }, \mathrm{HCO}_{3}}(t)\right) \times \text { flow }(t)\right\},
\end{aligned}
$$

which effectively provides a lower limit on the treatment effect.

We can also derive an upper limit for the treatment effect from Reaction (R1). For an ERW treatment, transient changes in the export of ions not derived from the applied minerals may occur, but we consider that the cations released from the applied minerals comprise the most unambiguous treatment effect in our study. The charge associated with wollastonite-derived $\mathrm{Ca}^{2+}$ (Wo-Ca) determines the $\mathrm{CO}_{2}$ consumption associated with the HBEF wollastonite treatment. Our optimistic treatment effect based on calcium rather than bicarbonate is

$$
\text { Wo- } \mathrm{CO}_{2, \mathrm{Ca}}(t)=2 \times X_{\mathrm{Ca}} \times\left[\mathrm{Ca}^{2+}\right](t) \times \text { flow }(t) .
$$

Equations (3) and (4), together with our flux calculations accounting for sparsity of concentration data compared to daily flow data (Sect. 2.2.5), should help avoid major uncertainties in catchment-scale $\mathrm{CO}_{2}$ consumption calculations: the provenance of the cations and variations in concentration and discharge (Moon et al., 2014).

\subsubsection{Flux calculations}

To ensure that fluxes from our two watersheds were comparable and to correct for the sparsity of solute measurements compared to flow measurements, we created rolling annual flow-adjusted fluxes using Method 5 of Littlewood et al. (1998) at five evenly spaced points each year:

flux $=$ scale $\times\left[\frac{\sum_{i=1}^{M} C_{i} Q_{i}}{\sum_{i=1}^{M} Q_{i}}\right] \times\left[\frac{\sum_{k=1}^{N} Q_{k}}{N}\right]$,

where $Q_{i}$ is the measured instantaneous stream flow, $C_{i}$ is the concentration for sample $i, M$ is the number of streamwater chemistry samples in the year (usually 12 ), $Q_{k}$ is the $k$ th flow measurement, and $N$ is the number of flow measurements. In our case, daily flow measurements (Campbell, 2015) and approximately monthly stream-water samples (Driscoll, 2016b, a) were available. Therefore, the mean concentration for the preceding 12 months is multiplied by the mean flow for the same period, suitably scaled to get the total annual flux. Without sub-daily timestamps for the longitudinal stream-water chemistry data, we used daily total flows rather than instantaneous flows. Tests suggested that there was little difference between using mean daily instantaneous flows and the mean daily total flows.

\subsection{Greenhouse gas balance}

The success of any treatment for climate change mitigation is determined by the net greenhouse gas $\left(\mathrm{CO}_{2}\right.$ equivalent $)$ fluxes prior to and following treatment, at the treatment site and downstream. In addition to increased $\mathrm{CO}_{2}$ consumption, desirable outcomes for a treatment include increased ecosystem carbon storage in biomass and soils and decreases in ecosystem, downstream, and logistical greenhouse gas emissions.

\subsubsection{Greenhouse gas budget for the wollastonite treatment}

At the $\mathrm{HBEF}$, we have measured the $\mathrm{CO}_{2}$ consumption due to the wollastonite treatment in two different ways and these determine our range of values to be incorporated in our greenhouse gas (GHG) budget. Several other treatment effects can be estimated relative to the reference watershed, but some aspects of the total GHG balance are missing. For example, we have measurements of soil respiration (root + heterotrophic) and dissolved organic carbon (DOC) export in stream water, but we lack measurements of canopy respiration from leaves and stems and export of particulate organic carbon in stream water. Our partial greenhouse gas budget for the HBEF wollastonite treatment will therefore be given by

$$
\begin{aligned}
\Delta \mathrm{GHG} & =\Delta \text { wood }+\Delta \mathrm{SRESP}+\Delta \mathrm{CH} 4+\Delta \mathrm{N} 2 \mathrm{O} \\
& +\Delta \mathrm{CONS}+\Delta \mathrm{NO} 3 \mathrm{~N} 2 \mathrm{O}+\Delta \mathrm{DOC} \\
& + \text { LOGPEN },
\end{aligned}
$$

where our partial GHG treatment effect $(\Delta \mathrm{GHG})$ is the sum of greenhouse gas sink and source responses. Measured sinks for the wollastonite experiment include biomass in wood ( $\Delta$ wood), $\mathrm{CO}_{2}$ consumption ( $\triangle \mathrm{CONS}$ ), and a soil sink for methane $(\triangle \mathrm{CH} 4)$. Sources include $\mathrm{N}_{2} \mathrm{O}$ emissions from both soil $(\triangle \mathrm{N} 2 \mathrm{O})$ and exported nitrate $(\triangle \mathrm{NO} 3 \mathrm{~N} 2 \mathrm{O})$ and $\mathrm{CO}_{2}$ emissions from soil respiration $(\triangle \mathrm{SRESP})$, exported dissolved organic carbon $(\triangle \mathrm{DOC})$, and logistical operations (LOGPEN).

Sink effects are defined as positive if the sink increases and are given by the difference (treated - reference) between the two watersheds, whereas source effects are defined as 
positive for reductions in greenhouse gas emissions (reference - treated). With these definitions, penalties are negative and reduce $\triangle \mathrm{GHG}$ in Eq. (6). Logistical emissions and $\mathrm{CO}_{2}$ consumption due to weathering of applied wollastonite are zero for the reference watershed, so we expect LOGPEN to be negative and $\triangle$ CONS to be positive.

Wood is a longer-term carbon sink than leaves or twigs so we have chosen to let this represent our biomass increment. Equation (6) neglects ecosystem disturbances including fire and possible carbonate mineral precipitation in soils. There is no evidence for the latter at the HBEF.

We used a range of emissions factors for $\mathrm{N}_{2} \mathrm{O}$ to estimate the penalty associated with nitrate export $(\triangle \mathrm{NO} 3 \mathrm{~N} 2 \mathrm{O})$; low: $0.0017 \mathrm{~kg} \mathrm{~N}_{2} \mathrm{O}-\mathrm{N} \mathrm{kg}^{-1}$ DIN (Hu et al., 2016) and high: $0.0075 \mathrm{~kg} \mathrm{~N}_{2} \mathrm{O}-\mathrm{N} \mathrm{kg}^{-1}$ DIN (De Klein et al., 2006), where DIN is dissolved inorganic nitrogen dominated by nitrate. This $\mathrm{N}_{2} \mathrm{O}$ was then converted to $\mathrm{CO}_{2 \mathrm{e}}\left(\mathrm{CO}_{2}\right.$ equivalents in terms of cumulative radiative forcing) given the 100year time horizon global warming potential (Pachauri et al., 2014) $\left(\mathrm{GWP}_{100}\right)$ for $\mathrm{N}_{2} \mathrm{O}: 265 \mathrm{~g} \mathrm{CO}_{2 \mathrm{e}} \mathrm{g}^{-1} \mathrm{~N}_{2} \mathrm{O}$. Likewise, $\Delta \mathrm{CH} 4$ was converted to $\mathrm{CO}_{2 \mathrm{e}}\left(\mathrm{CO}_{2}\right.$ equivalents in terms of cumulative radiative forcing) given $\mathrm{GWP}_{100}$ for $\mathrm{CH}_{4}$ : $28 \mathrm{~g} \mathrm{CO}_{2 \mathrm{e}} \mathrm{g}^{-1} \mathrm{CH}_{4}$

\subsubsection{Carbon sequestration in wood}

We calculate our treatment effect on wood production as the difference between the treated and reference watershed mean wood production (Battles et al., 2014) over two 5-year periods. We considered these differences (treated - reference) to be an estimate of the treatment effect on potentially longterm (decades to centuries) biomass carbon sequestration. Assuming $46.5 \%$ of the woody biomass is carbon (Martin et al., 2018), our calculated cumulative additional C sequestration in the treated watershed over 10 years was $20.7 \mathrm{~mol} \mathrm{C} \mathrm{m}^{-2}\left(9.1 \mathrm{tCO}_{2} \mathrm{ha}^{-1}\right)$. Our optimistic and pessimistic values are derived from the $95 \%$ confidence intervals for the 5-year mean values (Battles et al., 2014).

\subsubsection{Greenhouse gas emissions from soils}

Measurements (Groffman, 2016) were taken at four elevations in the treated watershed and at points just west of the reference watershed starting in 2002 (Fig. 1). Gas samples were collected from chambers placed on three permanent PVC rings at each of these eight sites (Groffman, 2016). The data were not normally distributed so were analysed with Kruskal-Wallis tests at the 0.05 significance level; however, tests with one-way ANOVA produced the same overall results. All analyses were done in MATLAB R2016a.

Cumulative curves for each of the 24 chambers were generated by matching the dates of the measurements, excluding points which were missing data for any chamber and allowing up to a week's discrepancy between catchments. Nearly all discrepancies were within $1 \mathrm{~d}$. Assuming diurnal variation was minor compared to seasonal variation, each datum $\left(\mathrm{g} \mathrm{C} \mathrm{m}^{-2} \mathrm{~h}^{-1}\right)$ was multiplied by $24 \mathrm{~h}$ and by $30 \mathrm{~d}$ to get $\mathrm{g} \mathrm{C} \mathrm{m}^{-2}$ per month. There was no extrapolation to fill gaps in the dataset; results are internally consistent but not comparable to other datasets. We were particularly interested in the elevation-specific responses, as the different elevations have distinct tree species compositions and below-ground responses to the wollastonite treatment (Fahey et al., 2016).

The HBEF experimental watersheds are divided into $25 \times 25 \mathrm{~m}$ plots on slope-corrected grids. Vegetation has been surveyed four times since the late 1990s and assigned a zone designation in each plot (Driscoll et al., 2015a, b; Battles et al., 2015b, a) (Fig. S12). To estimate the respiration savings over the whole watershed, we added the areas of individual plots which were assigned to our four vegetation types (low, middle, and high hardwoods and spruce-fir). Because there were seven vegetation types in the datasets, we compared all types with pairwise Kruskal-Wallis tests at the 0.05 significance level using the basal area data for the six dominant tree species. Kruskal-Wallis tests were appropriate because the data, and therefore the differences from the means (residuals), were not normally distributed. These tests suggested that the "extra" vegetation types ("birch-fern glade" and "poor hardwoods" at high elevations and mid-elevations) could be combined with spruce-fir and high and middle hardwoods respectively. Watershed fractions for our combined forest types were 0.155 for spruce-fir, 0.16 for high hardwoods, 0.415 for middle hardwoods, and 0.27 for low hardwoods. When creating our composite treatment effects for the entire watershed, we considered a treatment effect to be present only where our statistical analyses suggested significantly different fluxes.

\subsubsection{Logistical carbon emissions costs}

We used the 1999 upstate New York $\mathrm{CO}_{2}$ emission factor for electricity generation from oil (United States Environmental Protection Agency, 1999) $\left(0.9 \mathrm{Mg} \mathrm{CO}_{2} \mathrm{MWh}^{-1}\right)$ and rearranged Eq. (28) of Stamboliadis et al. (2009):

$e_{\mathrm{p}}=\frac{\left[e^{\frac{(\ln s / \alpha)}{\mu}}\right]}{3600 \times 1000}$,

where the specific surface area $s\left(1600 \mathrm{~m}^{2} \mathrm{~kg}^{-1}\right.$ for our treatment) is related to the specific potential energy $e_{\mathrm{p}}$ of the material $\left(\mathrm{kJ} \mathrm{kg}^{-1}\right)$, with theoretical parameters (Stamboliadis et al., 2009) $\alpha=139 \mathrm{~m}^{2} \mathrm{~kJ}^{-1}$ and $\mu=0.469$ (dimensionless). We convert this potential energy to $\mathrm{MWh} \mathrm{t}^{-1} \mathrm{Qz}\left(3600 \mathrm{~s} \mathrm{~h}^{-1}\right.$ and $1000 \mathrm{kWh} \mathrm{MWh}^{-1}$ ). The equation was derived for quartz (Qz) which has hardness 7. Because wollastonite hardness is in the range 5-5.5, this equation may overestimate the energy needed to grind the wollastonite.

The main energy source in Allerton will have been coal, and the 1999 Illinois emissions factor (United States Environmental Protection Agency, 1999) is $1.1 \mathrm{Mg} \mathrm{CO}_{2} \mathrm{MWh}^{-1}$. 
The monetary cost is USD $0.041 \mathrm{kWh}^{-1}$ for pelletization of limestone fines and USD $0.85 \mathrm{t}^{-1}$ product, so we estimate $20.73 \mathrm{kWh} \mathrm{t}^{-1}$ product.

Road transport distances were estimated using Google Maps $(1397 \mathrm{~km}$ from Gouverneur to Allerton, $1757 \mathrm{~km}$ from Allerton to Woodstock, $408 \mathrm{~km}$ from Gouverneur to Woodstock). We used standard emissions ranges (Sims et al., 2014) for heavy-duty vehicles (HDVs) (70$190 \mathrm{~g} \mathrm{CO}_{2} \mathrm{~km}^{-1} \mathrm{t}$ per rock) and for short-haul cargo aircraft (1200-2900 $\left.\mathrm{g} \mathrm{CO}_{2} \mathrm{~km}^{-1} \mathrm{t}^{-1}\right)$. Calculation details are given in Table 2. The MATLAB script used for these calculations is available on request. Note that $t$ refers to megagrammes, not US short tons.

\section{Results}

\subsection{Wollastonite treatment increased stream-water $\mathrm{CO}_{2}$ export}

We first consider the time series of stream-water changes in $\mathrm{Ca}^{2+}$ concentrations in the treated $\left([\mathrm{Ca}]_{\text {Treated }}\right)$ and reference $\left([\mathrm{Ca}]_{\mathrm{Ref}}\right)$ watersheds. Immediately after treatment, $[\mathrm{Ca}]_{\text {Treated }}$ increased from $<30$ to $\sim 60 \mu \mathrm{mol} \mathrm{L}^{-1}$ and then slowly declined over the next decade, remaining persistently above $[\mathrm{Ca}]_{\text {Ref }}$ for 15 years (Fig. 2a). The initial posttreatment peak represents dissolution of wollastonite within the stream (Peters et al., 2004) and release of calcium from hyporheic exchange during the first few years (Shao et al., 2016; Nezat et al., 2010). Retention of $\mathrm{Ca}^{2+}$ ions liberated by wollastonite dissolution (Wo-Ca) in the watershed soils (Nezat et al., 2010) and sequestration into tree biomass (Balogh-Brunstad et al., 2008; Nezat et al., 2010) delayed appearance in stream water for 3 years (Shao et al., 2016; Nezat et al., 2010). Subsequently, $[\mathrm{Ca}]_{\text {Treated }}$ remained approximately double $[\mathrm{Ca}]_{\text {Ref }}$, with a $\sim 30 \%$ contribution from non-wollastonite $\mathrm{Ca}^{2+}$ until 2012. Towards the end of the time series, increased seasonal $\mathrm{NO}_{3}^{-}$export in the treated watershed between 2012 and 2014 (Rosi-Marshall et al., 2016) led to Wo-Ca displacing non-Wo-Ca from the soil exchanger.

We derived the annual export of $\mathrm{Ca}^{2+}$ from the treated and reference watersheds as the product of mean annual flowadjusted $\mathrm{Ca}^{2+}$ stream-water concentrations and annual flow (Fig. 2b) (Methods). After accounting for variations in flow, increased stream-water $\mathrm{Ca}^{2+}$ concentrations in the treated watershed are translated into a 2-fold increase in total $\mathrm{Ca}^{2+}$ export relative to the reference watershed that was maintained for 15 years until 2015 through this analysis period. Overall, the wollastonite treatment resulted in a sharp spike in calculated $\mathrm{CO}_{2}$ consumption (Wo- $\mathrm{CO}_{2, \mathrm{Ca}}$ ) that decreased but remained elevated as a result of the treatment (Fig. 2c).

Temporal patterns in modelled stream-water bicarbonate concentration in both treated and reference watersheds (Fig. 2d), and the corresponding total annual $\mathrm{CO}_{2}$ consumption $\left(\mathrm{CO}_{2, \mathrm{HCO}_{3}}\right)$ (Fig. 2e) and $\mathrm{CO}_{2}$ consumption result- ing from treatment $\left(\mathrm{Wo}-\mathrm{CO}_{2,} \mathrm{HCO}_{3}\right)$ (Fig. 2f), largely mirror changes in stream-water $\mathrm{Ca}^{2+}$ concentrations but are modified by the supply and loss of anions. Calculated flowadjusted $\mathrm{CO}_{2}$ consumption (Fig. 2e) peaked 2-3 years posttreatment with a broader peak in $\mathrm{CO}_{2}$ consumption evident in 2007-2012 corresponding to declining legacy effects of acid rain until transient $\mathrm{NO}_{3}^{-}$peaks appeared 2012-2015. Wo- $\mathrm{CO}_{2, \mathrm{HCO}_{3}}$ shows a pattern that mirrors Wo- $\mathrm{CO}_{2, \mathrm{Ca}}$ but is generally 5 times lower (Fig. 2c, f).

\subsection{Sulfuric, nitric, and organic acids reduce CDR}

We next undertook sensitivity analyses to investigate the effects of acid deposition, increased $\mathrm{NO}_{3}^{-}$, and organic acid export from the treated watershed on bicarbonate concentrations and resulting $\mathrm{CO}_{2}$ consumption (Fig. S5). In a "low$\mathrm{SO}_{4}$ " scenario (Fig. S5a-c), we sought to understand the effects of acid deposition by replacing the mean monthly time series of stream-water and rainwater $\mathrm{SO}_{4}^{2-}$ for the treated watershed with a new time series (purple curve, Fig. S5a) created by repeating the post- 2010 datasets, which reflect diminished acid deposition following emission controls from the US Clean Air Act (Likens and Bailey, 2014). Removing acid rain effects in this manner dramatically increased the calculated bicarbonate concentrations and total annual $\mathrm{CO}_{2}$ consumption $\left(\mathrm{CO}_{2, \mathrm{HCO}_{3}}\right)$, increasing the initial spikes resulting from the wollastonite treatment in both by at least 4-fold (purple curves, Fig. S5b, c). An additional legacy of acidification in North American forests (Harrison et al., 1989) is $\mathrm{SO}_{4}^{2-}$ retention on soil clay mineral $\mathrm{Fe}$ and $\mathrm{Al}$ oxides (Fuller et al., 1987), which were subsequently released by increased soil pH following wollastonite weathering (Shao et al., 2016; Fakhraei et al., 2016). To assess the effect of this legacy $\mathrm{SO}_{4}^{2-}$, we ran simulations for the treated watershed substituting the lower stream-water $\mathrm{SO}_{4}^{2-}$ concentrations from the reference watershed (T REF, green curves, Fig. S5b, c). Results suggest that legacy $\mathrm{SO}_{4}^{2-}$ accounts for over half of the total acid deposition effect on increased $\left[\mathrm{HCO}_{3}^{-}\right]$and $\mathrm{CO}_{2}$ consumption in the simulations.

In the "ref $\mathrm{NO}_{3}$ " scenario (Fig. S5d-f), seasonal spikes in stream-water export of $\mathrm{NO}_{3}^{-}$recorded from the treated watershed between 2012 and 2015 were removed by substituting the reference watershed stream-water $\mathrm{NO}_{3}^{-}$concentration measurements lacking these spikes. This manipulation markedly increased modelled bicarbonate (Fig. S5e) and mean annual $\mathrm{CO}_{2}$ consumption (Fig. S5f). To quantify the effects of organic acids on bicarbonate production in the treated watershed, we ran " $+\mathrm{OA}$ " and " $-\mathrm{OA}$ " simulations, i.e. with and without accounting for organic acids respectively (Fig. S5g-i). Results showed that removing OA from our simulations also increased modelled stream-water bicarbonate concentration (Fig. S5h), and resulting $\mathrm{CO}_{2}$ consumption (Fig. S5i), in the treated watershed. 
Table 2. Logistical penalty calculations for the Hubbard Brook wollastonite treatment.

\begin{tabular}{|c|c|}
\hline Penalty element & Value and calculation with units \\
\hline $\begin{array}{l}\text { Mass of wollastonite }\left(\mathrm{CaSiO}_{3}\right) \text { shipped to Allerton } \\
\left(\mathrm{t}^{\mathrm{a}} \mathrm{Wo}\right)\end{array}$ & $109665 \mathrm{lbs}$ or $49.7432073 \mathrm{t}$ Wo \\
\hline Mass of pellets shipped from Allerton (t pellets) & $112992 \mathrm{lbs}$ or $51.2523091 \mathrm{t}$ pellets \\
\hline Ratio of pellet mass to Wollastonite mass & $1.0368=51.25 \mathrm{t}$ pellets $/ 49.74 \mathrm{t} \mathrm{Wo}$ \\
\hline HDV transport distance $(\mathrm{km})$ & $\begin{array}{l}3154 \mathrm{~km}=1397 \mathrm{~km}(\text { Gouverneur to Allerton })+1757 \mathrm{~km}(\text { Allerton to } \\
\text { Woodstock })\end{array}$ \\
\hline $\begin{array}{l}\text { Transport distance for "local pelletization" calcula- } \\
\text { tion }(\mathrm{km})\end{array}$ & 408 km (Gouverneur to Woodstock) \\
\hline $\begin{array}{l}\text { Optimistic transport emissions }\left(\mathrm{g} \mathrm{CO}_{2} \mathrm{~g}^{-1} \text { Wo }\right. \\
\text { applied) }\end{array}$ & $\begin{array}{l}0.229 \mathrm{~g} \mathrm{CO}_{2} \mathrm{~g}^{-1} \text { Wo applied }=70 \mathrm{~g} \mathrm{CO}_{2} \mathrm{~km}^{-1} \text { shipped } \mathrm{t}^{-1} \text { shipped } \\
\times((1397 \mathrm{~km} \times 49.74 \mathrm{t} \text { Wo shipped })+(1757 \mathrm{~km} \times 51.25 \mathrm{t} \text { pellets } \\
\text { shipped })) / 48.86 \times 10^{6} \mathrm{~g} \text { Wo applied }\end{array}$ \\
\hline $\begin{array}{l}\text { Pessimistic transport emissions }\left(\mathrm{g} \mathrm{CO}_{2} \mathrm{~g}^{-1} \text { Wo }\right. \\
\text { applied) }\end{array}$ & $\begin{array}{l}0.620 \mathrm{~g} \mathrm{CO}_{2} \mathrm{~g}^{-1} \text { Wo applied }=190 \mathrm{~g} \mathrm{CO}_{2} \mathrm{~km}^{-1} \text { shipped } \mathrm{t}^{-1} \text { shipped } \\
\times((1397 \mathrm{~km} \times 49.74 \mathrm{t} \text { Wo shipped })+(1757 \mathrm{~km} \times 51.25 \mathrm{t} \text { pellets } \\
\text { shipped })) / 48.86 \times 10^{6} \mathrm{~g} \text { Wo applied }\end{array}$ \\
\hline $\begin{array}{l}\text { Mass of pellets deployed by helicopter ( } \mathrm{t} \text { pellets } \\
\text { applied) }\end{array}$ & $110992 \mathrm{lbs}$ or $50.3451243 \mathrm{t}$ pellets applied \\
\hline $\begin{array}{l}\text { Mass of wollastonite deployed by helicopter ( } \mathrm{t} \text { Wo } \\
\text { applied) }\end{array}$ & $48.86 \mathrm{t}$ Wo applied $=50.345 \mathrm{t}$ pellets applied $/ 1.03684$ \\
\hline Total area treated (ha) & $\begin{array}{l}14.2 \text { ha }=11.8 \text { ha watershed plus } 2.4 \text { ha "destructive area" along the } \\
\text { western edge }\end{array}$ \\
\hline $\begin{array}{l}\text { Nominal mean round trip flight distance }(\mathrm{km} \text {, } \\
\text { Woodstock to watershed and back) }\end{array}$ & $5 \mathrm{~km}$ \\
\hline Number of flights (1 short ton hopper capacity) ${ }^{b}$ & $55.5=50.345 \mathrm{t}$ pellets $/ 0.907 \mathrm{t}$ per trip \\
\hline $\begin{array}{l}\text { Molar mass of wollastonite } \mathrm{CaSiO}_{3} \\
(\mathrm{~g} \mathrm{Wo} \mathrm{mol}-1 \text { Wo })\end{array}$ & $\begin{array}{l}116.17 \mathrm{~g} \mathrm{Wo} \mathrm{mol}^{-1} \mathrm{Wo}=40.08 \mathrm{~g} \mathrm{Ca} \mathrm{mol}^{-1} \mathrm{Ca}+28.09 \mathrm{~g} \mathrm{Si} \mathrm{mol}^{-1} \mathrm{Si} \\
+3 \times 16 \mathrm{~g} \mathrm{O} \mathrm{mol}^{-1} \mathrm{O}\end{array}$ \\
\hline Molar mass of $\mathrm{CO}_{2}\left(\mathrm{~g} \mathrm{CO}_{2} \mathrm{~mol}^{-1} \mathrm{CO}_{2}\right)$ & $44.01 \mathrm{~g} \mathrm{CO}_{2} \mathrm{~mol}^{-1} \mathrm{CO}_{2}=2 \times 16 \mathrm{~g} \mathrm{O} \mathrm{mol}^{-1} \mathrm{O}+12.01 \mathrm{~g} \mathrm{C} \mathrm{mol}^{-1} \mathrm{C}$ \\
\hline Optimistic spreading emissions $\left(\mathrm{mol} \mathrm{CO}_{2} \mathrm{ha}^{-1}\right)$ & $\begin{array}{l}483.36 \mathrm{~mol} \mathrm{CO}_{2} \mathrm{ha}^{-1}=1200 \mathrm{~g} \mathrm{CO}_{2} \mathrm{~km}^{-1} \mathrm{t}^{-1} \times 5 \mathrm{~km} \times 50.345 \mathrm{t} \\
\text { pellets } / 44.01 \mathrm{~g} \mathrm{CO}_{2} \mathrm{~mol}^{-1} \mathrm{CO}_{2} / 14.2 \mathrm{ha}\end{array}$ \\
\hline Optimistic spreading emissions ( $\left.\mathrm{g} \mathrm{CO}_{2} \mathrm{~g}^{-1} \mathrm{Wo}\right)$ & $\begin{array}{l}0.006 \mathrm{~g} \mathrm{CO}_{2} \mathrm{~g}^{-1} \mathrm{Wo}=1200 \mathrm{~g} \mathrm{CO}_{2} \mathrm{~km}^{-1} \mathrm{t}^{-1} \times 5 \mathrm{~km} \times 50.345 \mathrm{t} \\
\text { pellets } / 48.86 / 10^{6} \mathrm{~g} \mathrm{Wo}\end{array}$ \\
\hline Pessimistic spreading emissions $\left(\mathrm{mol} \mathrm{CO}_{2} \mathrm{ha}^{-1}\right)$ & $\begin{array}{l}1168.1 \mathrm{~mol} \mathrm{CO}_{2} \mathrm{ha}^{-1}=2900 \mathrm{~g} \mathrm{CO}_{2} \mathrm{~km}^{-1} \mathrm{t}^{-1} \times 5 \mathrm{~km} \times 50.345 \mathrm{t} \\
\text { pellets } / 44.01 \mathrm{~g} \mathrm{CO}_{2} \mathrm{~mol}^{-1} \mathrm{CO}_{2} / 14.2 \mathrm{ha}\end{array}$ \\
\hline Pessimistic spreading emissions $\left(\mathrm{g} \mathrm{CO}_{2} \mathrm{~g}^{-1} \mathrm{Wo}\right)$ & $\begin{array}{l}0.015 \mathrm{~g} \mathrm{CO}_{2} \mathrm{~g}^{-1} \text { Wo applied }=2900 \mathrm{~g} \mathrm{CO}_{2} \mathrm{~km}^{-1} \mathrm{t}^{-1} \times 5 \mathrm{~km} \times \\
50.345 \mathrm{t} \text { pellets } / 48.86 \times 10^{6} \mathrm{~g} \text { Wo applied }\end{array}$ \\
\hline
\end{tabular}

\subsection{Effects of increasing wollastonite treatment}

Because the HBEF application rate $\left(3.44 \mathrm{tha}^{-1}\right)$ is smaller than the $10-50 \mathrm{t} \mathrm{ha}^{-1}$ suggested for ERW strategies (Strefler et al., 2018; Beerling et al., 2018), we simulated the possible effects of a 10-fold increase in the stream-water $\mathrm{Ca}^{2+}$ concentrations on bicarbonate production (Fig. S6a) and $\mathrm{CO}_{2}$ consumption (Fig. S6b). In this initial assessment, we assume stream-water responses are directly proportional to wollastonite application rate, i.e. $34.4 \mathrm{tha}^{-1}$, and that all other variables remained unchanged. Results show that after 15 years, cumulative $\mathrm{Wo}_{-} \mathrm{CO}_{2, \mathrm{HCO}_{3}}$ is $73 \%$ of Wo- $\mathrm{CO}_{2, \mathrm{Ca}}$ (Fig. S6c), as opposed to less than $20 \%$ for the actual rate of $3.44 \mathrm{tha}^{-1}$ (Table 3). These results suggest that at higher application 


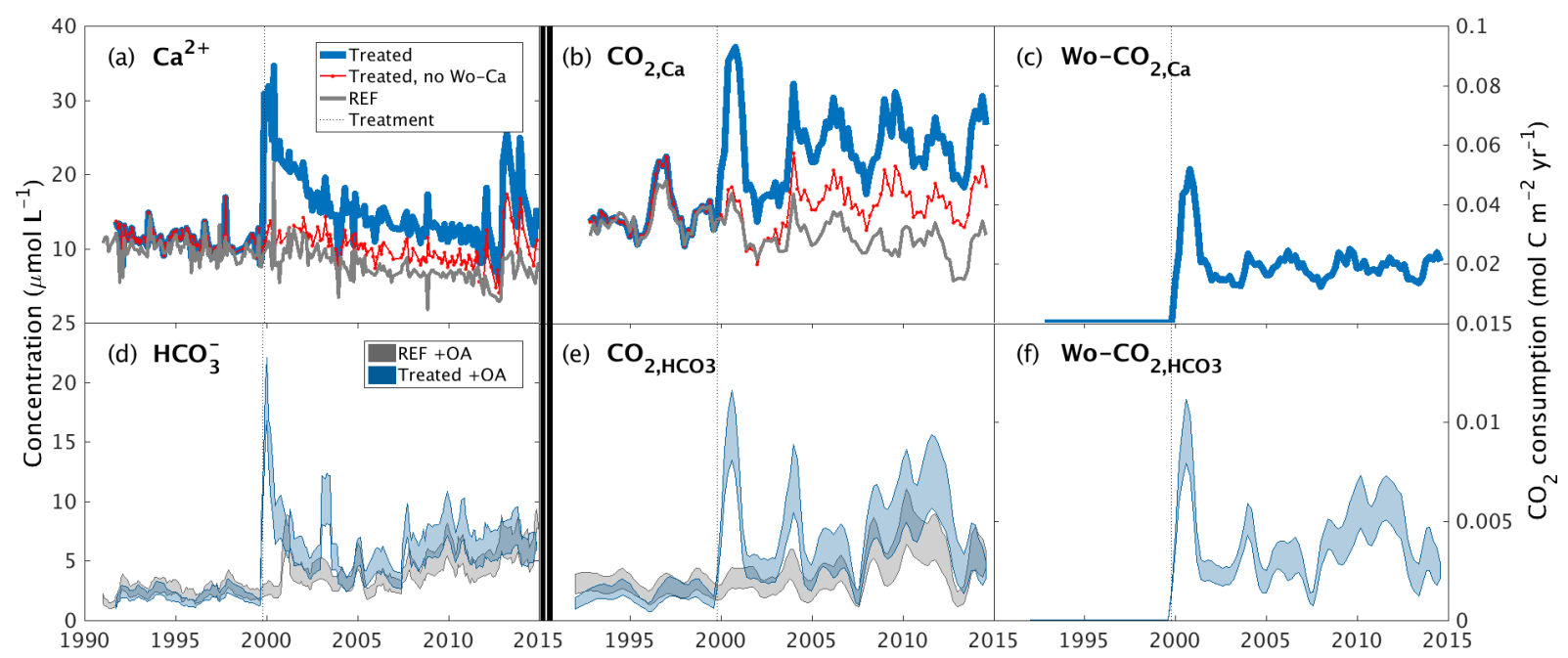

Figure 2. Inorganic $\mathrm{CO}_{2}$ capture at the Hubbard Brook Experimental Forest. (a) Observed calcium and (b) calcium export in the reference (grey) and treated (blue) watersheds along with the contribution from sources other than wollastonite (red) and the time of treatment (vertical dotted line). (c) Calculated $\mathrm{CO}_{2}$ consumption due to the treatment (Wo- $\mathrm{CO}_{2, \mathrm{Ca}}$, Eq. 9). (d) Modelled stream-water bicarbonate, (e) $\mathrm{CO} 2$ consumption $\left(\mathrm{CO}_{2, \mathrm{HCO}_{3}}\right.$, Eq. 5), and (f) $\mathrm{CO}_{2}$ consumption due to the treatment (Wo- $\mathrm{CO}_{2, \mathrm{HCO}_{3}}$, Eq. 7); colours as for calcium. Simulations (d-f) account for the presence of organic acids (+OA). All calcium export (b) and $\mathrm{CO}_{2}$ consumption curves (c, e, f) were calculated with flow-normalized concentrations and corrected for sparsity of samples (Methods).

rates of wollastonite, the details of the $\mathrm{CO}_{2}$ consumption calculations become less important.

\subsection{Amplification of organic carbon sequestration by wollastonite treatment}

In reversing long-term $\mathrm{Ca}^{2+}$ depletion of soils, the silicate rock treatment significantly increased forest growth and wood production between $2-12$ years post-treatment relative to the reference watershed (Battles et al., 2014). This forest response increased total carbon sequestration by $20.7 \mathrm{~mol} \mathrm{C} \mathrm{m}^{-2}$ or $9.1 \mathrm{tCO}_{2} \mathrm{ha}^{-1}$ during those 10 years as a result of the treatment (Methods).

Changes in greenhouse gas (GHG) emissions from soils represent a further route to affecting the climate mitigation potential of the wollastonite treatment. Despite a rapid increase of one $\mathrm{pH}$ unit in the upper organic soil horizon (Oie), soil respiration $\mathrm{CO}_{2}$ fluxes showed no significant difference between watersheds during the first 3 years after treatment (Groffman et al., 2006). However, our analysis of newly available longer-term datasets indicates that the treatment significantly reduced soil respiration in the high-elevation hardwood zone $(\sim 660-845 \mathrm{~m}$ a.s.l. $)$ $\left(\chi^{2}(1,270)=17.2, P<0.001\right)$, possibly due to reduced fineroot biomass (Fahey et al., 2016) rather than changes in microbial activity (Groffman et al., 2006). No significant effects on soil respiration were detected in any of the other HBEF vegetation zones (Fig. 3). The wollastonite treatment increased the soil sink strength for $\mathrm{CH}_{4}$ $\left(\chi^{2}(1,266)=30.8, P<0.001\right)$ in the low-elevation hardwood zone (482-565 $\mathrm{m}$ a.s.l.), while it decreased in the high- elevation zone $\left(\chi^{2}(1,268)=22.3, P<0.001\right)$ (Supplement, Fig. S8). There were no significant treatment effects on soil $\mathrm{N}_{2} \mathrm{O}$ fluxes in any vegetation zone (Supplement).

\subsection{Logistical $\mathrm{CO}_{2}$ emissions and net $\mathrm{CDR}$}

We next considered carbon emissions (penalties) for logistical operations involved in mining, grinding, transporting, and applying the wollastonite (Fig. 4, Table 2). In the HBEF experiment, wollastonite was mined and milled on site near Gouverneur, New York. We used $\mathrm{CO}_{2}$ emissions factors for electricity generation in upstate New York (United States Environmental Protection Agency, 1999) to estimate the maximum $\mathrm{CO}_{2}$ penalty for mining and grinding to the mean particle size $16 \mu \mathrm{m}$ diameter (Methods). However, local hydropower (Energy Information Administration, 1997) and regional nuclear power suggest these costs could have been zero. This would represent a substantial carbon saving for the overall ERW process relative to prior expectation of ERW studies in which grinding $\mathrm{CO}_{2}$ emissions account for up to $30 \%$ reduction in ERW-CDR efficiency (Renforth, 2012; Moosdorf et al., 2014).

In the HBEF experiment, the milled wollastonite was transported by highway to Allerton, Illinois, for pelletization and then returned to the staging area near Woodstock, New Hampshire (round trip $>3150 \mathrm{~km}$ ). Transportation $\mathrm{CO}_{2}$ emissions were $0.22-0.61 \mathrm{tCO}_{2} \mathrm{tWo}^{-1}$. Given coal power in central Illinois, we estimate pelletization emitted up to $0.02 \mathrm{tCO}_{2} \mathrm{t} \mathrm{Wo}^{-1}$ (Methods). Application at Hubbard Brook occurred via $55 \sim 5 \mathrm{~km}$ helicopter flights, which gives a further $\mathrm{CO}_{2}$ cost of $0.01-0.15 \mathrm{tCO}_{2} \mathrm{tWo}^{-1}$. In total, these lo- 
Table 3. Cumulative fluxes from treatment date calculated with stream-water partial pressure of $\mathrm{CO}_{2}$ (gas) $=3.63 \times$ atmospheric $\mathrm{CO}_{2}$ partial pressure measured at Mauna Loa (Tans and Keeling, 2017) (see Methods). DIC: dissolved inorganic carbon. Scenarios are defined in the main text.

\begin{tabular}{|c|c|c|c|c|c|c|c|c|}
\hline \multicolumn{9}{|c|}{ Cumulative fluxes 1 year post-treatment date (19 October 2000$)$} \\
\hline \multirow[t]{2}{*}{ Watershed } & \multirow[t]{2}{*}{ Scenario } & \multirow[t]{2}{*}{ Org. acids } & $\begin{array}{r}\mathrm{CO}_{2, \text { ions }} \\
(\text { Eq. 2) }\end{array}$ & $\begin{array}{r}\mathrm{Wo} \mathrm{CO}_{2}, \mathrm{Ca} \\
(\mathrm{Eq} .4)\end{array}$ & DIC & $\mathrm{HCO}_{3}$ & $\begin{array}{r}\mathrm{CO}_{2, \mathrm{HCO}_{3}} \\
\text { (Eq. 1) }\end{array}$ & 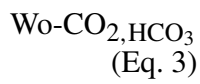 \\
\hline & & & \multicolumn{6}{|c|}{$\mathrm{molC} \mathrm{m}^{-2}$} \\
\hline REF (6) & baseline & $+\mathrm{OA}$ & -0.003 & 0 & 0.084 & 0.002 & 0.002 & 0 \\
\hline Treated (1) & baseline & $+\mathrm{OA}$ & 0.047 & 0.052 & 0.086 & 0.011 & 0.011 & 0.011 \\
\hline Treated (1) & baseline & $-\mathrm{OA}$ & 0.047 & 0.052 & 0.094 & 0.019 & 0.019 & 0.018 \\
\hline Treated (1) & Low $\mathrm{SO}_{4}$ & $+\mathrm{OA}$ & 0.083 & 0.052 & 0.117 & 0.043 & 0.042 & 0.039 \\
\hline Treated (1) & $\mathrm{REF} \mathrm{NO}_{3}$ & $+\mathrm{OA}$ & 0.047 & 0.052 & 0.105 & 0.030 & 0.030 & 0.029 \\
\hline Treated (1) & WoX10 & $+\mathrm{OA}$ & 0.513 & 0.534 & 0.533 & 0.457 & 0.457 & 0.457 \\
\hline
\end{tabular}

Cumulative fluxes 15 years post-treatment (20 November 2014)

\begin{tabular}{|c|c|c|c|c|c|c|c|c|}
\hline \multirow[t]{2}{*}{ Watershed } & \multirow[t]{2}{*}{ Scenario } & \multirow[t]{2}{*}{ Org. acids } & $\begin{array}{r}\mathrm{CO}_{2, \text { ions }} \\
\text { (Eq. 2) }\end{array}$ & $\begin{array}{r}\mathrm{Wo} \mathrm{CO}_{2, \mathrm{Ca}} \\
(\mathrm{Eq} .4)\end{array}$ & DIC & $\mathrm{HCO}_{3}$ & $\begin{array}{r}\mathrm{CO}_{2, \mathrm{HCO}_{3}} \\
\text { (Eq. 1) }\end{array}$ & $\begin{array}{r}\mathrm{Wo}-\mathrm{CO}_{2, \mathrm{HCO}_{3}} \\
\text { (Eq. 3) }\end{array}$ \\
\hline & & & \multicolumn{6}{|c|}{$\mathrm{mol} \mathrm{Cm^{-2 }}$} \\
\hline REF (6) & baseline & $+\mathrm{OA}$ & -0.274 & 0 & 1.307 & 0.052 & 0.036 & 0 \\
\hline Treated (1) & baseline & $+\mathrm{OA}$ & -0.044 & 0.294 & 1.299 & 0.083 & 0.064 & 0.057 \\
\hline Treated (1) & baseline & $-\mathrm{OA}$ & -0.044 & 0.294 & 1.414 & 0.198 & 0.179 & 0.145 \\
\hline Treated (1) & Low $\mathrm{SO}_{4}$ & $+\mathrm{OA}$ & 0.269 & 0.294 & 1.523 & 0.307 & 0.270 & 0.179 \\
\hline Treated (1) & $\mathrm{REF} \mathrm{NO}_{3}$ & $+\mathrm{OA}$ & -0.044 & 0.294 & 1.410 & 0.194 & 0.175 & 0.127 \\
\hline Treated (1) & WoX10 & $+\mathrm{OA}$ & 2.600 & 3.275 & 3.626 & 2.406 & 2.387 & 2.380 \\
\hline
\end{tabular}

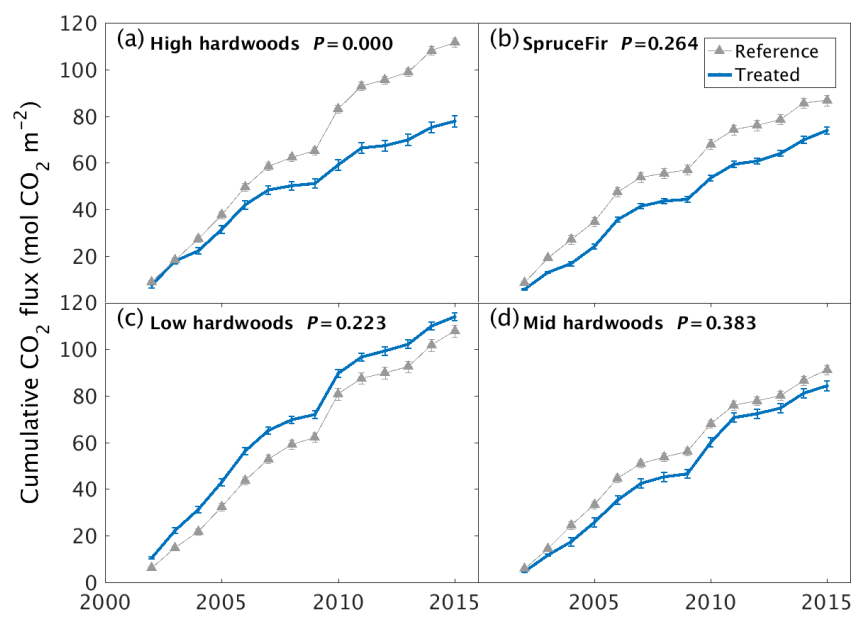

Figure 3. Long-term soil respiration responses to wollastonite treatment at Hubbard Brook Experimental Forest. Cumulative soil $\mathrm{CO}_{2}$ respiration responses of treated and untreated (a) high-elevation hardwoods, (b) high-elevation conifers, (c) low-elevation hardwoods, or (d) mid-elevation hardwoods. Plots show cumulative means $\pm 1 \mathrm{SE}$ for three chamber measurements at each site and time. Reference data were collected from untreated forests immediately adjacent to the western edge of our reference catchment. $P$ values from Kruskal-Wallis tests comparing treated and reference raw data (Supplement) are shown.

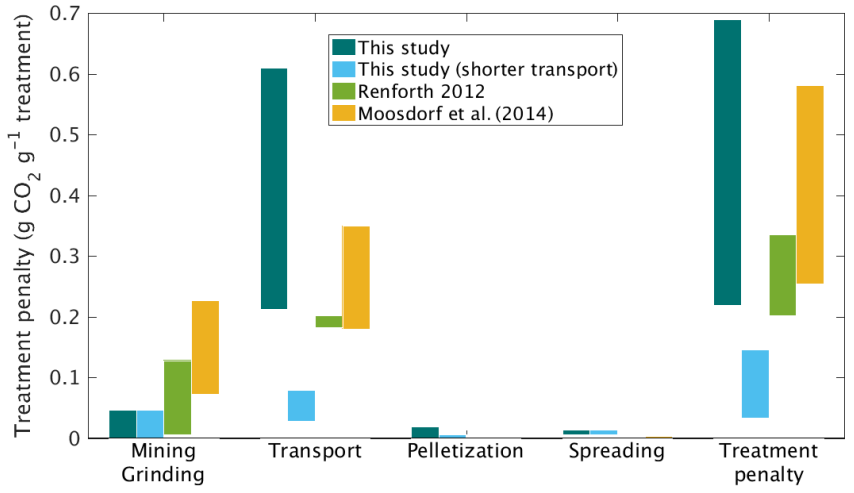

Figure 4. Carbon penalties for the wollastonite treatment. Carbon penalties for logistic elements of the treatment are compared with literature estimates for large-scale roll-out of enhanced rock weathering for the HBEF treatment $\left(3.44 \mathrm{tha}^{-1}\right)$, with and without longdistance transport for pelletization.

gistical operations emitted $0.23-0.69 \mathrm{tCO}_{2} \mathrm{tWo}^{-1}$ or 0.8 $2.4 \mathrm{t} \mathrm{CO}_{2} \mathrm{ha}^{-1}$ for the 11.8 ha of the HBEF treated watershed (Table 4). However, local pelletization could have reduced heavy-duty vehicle (HDV) transport distance to $\sim 400 \mathrm{~km}$ and lowered total $\mathrm{CO}_{2}$ emitted during logistical operations to $0.04-0.15 \mathrm{tCO}_{2} \mathrm{t} \mathrm{Wo}^{-1}$. At other forested sites, where winddrift of material is not critical, pelletization may not be necessary. 
Table 4. Measured elements of the treatment effect on the greenhouse gas budget for the Hubbard Brook Experimental Forest wollastonite experiment.

\begin{tabular}{|c|c|c|c|}
\hline Equation (14) & Greenhouse gas sinks $^{\mathrm{a}}$ and emissions ${ }^{\mathrm{a}}\left(\mathrm{tCO}_{2 \mathrm{e}} \mathrm{ha}^{-2}\right)$ & Pessimistic & Optimistic \\
\hline \multicolumn{4}{|c|}{ Ecosystem responses $^{\mathrm{b}}$} \\
\hline$\Delta$ wood & Wood production sink increased over 10 years ${ }^{\mathrm{c}}$ & 8.946 & 9.542 \\
\hline$\triangle$ SRESP & Soil respiratory $\mathrm{CO}_{2}$ emissions have reduced ${ }^{\mathrm{a}}$ since 2002 & 2.213 & 2.646 \\
\hline$\Delta \mathrm{CH} 4$ & Soil methane sink has increased since 2002 & 0.015 & 0.029 \\
\hline \multirow[t]{2}{*}{$\Delta \mathrm{N} 2 \mathrm{O}$} & Soil $\mathrm{N}_{2} \mathrm{O}$ emissions since 2002 (no significant difference) & 0 & 0 \\
\hline & Net ecosystem response at the treatment site through 2014 & 11.174 & 12.218 \\
\hline \multicolumn{4}{|c|}{ Downstream sequestration and emissions responses } \\
\hline$\triangle \mathrm{CONS}$ & $\mathrm{CO}_{2}$ consumption sink through $2014\left(\mathrm{Wo}-\mathrm{CO}_{2}, \mathrm{HCO}_{3}\right.$ and $\left.\mathrm{Wo}-\mathrm{CO}_{2, \mathrm{Ca}}\right)$ & 0.025 & 0.129 \\
\hline$\triangle \mathrm{NO} 3 \mathrm{~N} 2 \mathrm{O}$ & Downstream $\mathrm{N}_{2} \mathrm{O}$ emissions ${ }^{\mathrm{d}}$ from treatment date through 2014 & -0.071 & -0.016 \\
\hline \multirow{2}{*}{$\triangle \mathrm{DOC}$} & DOC export emissions ${ }^{\mathrm{d}, \mathrm{e}}$ from treatment date through 2014 & -0.203 & 0 \\
\hline & Net downstream balance through 2014 & -0.228 & -0.129 \\
\hline \multicolumn{4}{|l|}{ Logistics: } \\
\hline & Mining/grinding given hydro or nuclear/petroleum power & -0.162 & 0 \\
\hline & Helicopter ( $\sim 555 \mathrm{~km}$ flights $)$ & -0.051 & -0.021 \\
\hline & HDV transport (New York to Illinois to New Hampshire) & -2.135 & -0.787 \\
\hline & Pelletization (in Illinois, coal power) & -0.068 & 0 \\
\hline LOGPEN & Total logistical emissions & -2.416 & -0.808 \\
\hline$\Delta \mathrm{GHG}$ & Partial treatment effect on greenhouse gas balance & 8.509 & 11.523 \\
\hline
\end{tabular}

${ }^{a}$ Defined as the difference between watersheds: treated - reference for sinks and reference - treated for emissions. ${ }^{\mathrm{b}}$ Some possible treatment responses such as canopy respiration and particulate organic carbon export are unknown. ${ }^{\mathrm{c}}$ After Battles et al. (2014). We have not attempted to extrapolate these results. ${ }^{\mathrm{d}} \triangle \mathrm{DOC}$ and $\triangle \mathrm{NO} 3 \mathrm{~N} 2 \mathrm{O}$ are penalties because these lead to $\mathrm{CO}_{2}$ and $\mathrm{N}_{2} \mathrm{O}$ emissions downstream. ${ }^{\mathrm{e}}$ The "optimistic" value for DOC assumes complete burial and undesirable low-oxygen conditions in downstream waters.

These carbon emission penalties must be subtracted from watershed carbon removal to calculate net CDR for the wollastonite treatment at HBEF (Fig. 5; Table 4). Compared in this way, we find increased wood production over 10 years (Battles et al., 2014) repays the total logistical $\mathrm{CO}_{2}$ costs 4 12 times over. The components (Fig. 5; Table 4) comprise 8.5-11.5 $\mathrm{tCO}_{2} \mathrm{ha}^{-1}$ of the total GHG budget associated with the wollastonite treatment (Methods). These figures would increase to $10.4-12.2 \mathrm{tCO}_{2} \mathrm{ha}^{-1}$ if the wollastonite had been pelletized anywhere along the route from Gouverneur to New Hampshire.

Wollastonite treatment effects on stream-water chemistry play a minor role in the greenhouse gas budget (Fig. 5; Table 4). For our hypothetical 10 -fold higher treatment (34.4 t ha $\left.{ }^{-1}\right), \mathrm{CO}_{2}$ consumption calculated by assumed calcium release is $\sim 10$ times higher, but carbon emission penalties scale with increased rock mass. Assuming pelletization near the mine to reduce transport costs, the total logistical penalty would be $1.2-5.1 \mathrm{tCO}_{2} \mathrm{ha}^{-1}$. In total, net CDR would be $6.8-12.4 \mathrm{tCO}_{2} \mathrm{ha}^{-1}$ for the 10-fold larger treatment if none of the other GHG fluxes changed. We have not attempted to extrapolate other forest biomass and soil GHG fluxes or stream-water DOC and $\mathrm{NO}_{3}^{-}$responses.

\subsection{Potential for deployment at larger scales}

The HBEF forests are representative of a major area of eastern North America receiving acid deposition since the 1950s (Likens and Bailey, 2014) which may be suitable for remediation and carbon capture via ERW treatment with a silicate rock or mineral. For example, the Appalachian and Laurentian-Acadian northern hardwood forests (NHWFs) covering a combined area of $0.137 \mathrm{Mkm}^{2}$ in the United States (Ferree and Anderson, 2013) have the same dominant hardwood trees as the HBEF experimental watersheds (Fagus grandifolia, Betula alleghaniensis, and Acer saccharum). Acid deposition exceeded "critical loads" likely to harm ecosystems in almost 9000 ha of New Hampshire's Acer saccharum stands (NHAs) (Schaberg et al., 2010). These forests might be expected to respond similarly to a wollastonite treatment. The acid-sensitive trees Acer saccharum and Picea rubens are also widely distributed along the high-elevation acid sensitive regions of the Appalachian Mountains which have already been impacted by acid deposition (Lawrence et al., 2015). We define this as a $40 \mathrm{~km}$ corridor along the Appalachian Mountains comprising $0.14 \mathrm{Mkm}^{2}$ and overlapping with the High Allegheny Plateau (HAL) ecoregion where Acer saccharum is declining above $\sim 550 \mathrm{~m}$ a.s.l. (Bailey et al., 2004) $\left(0.07 \mathrm{Mkm}^{2}\right)$. 


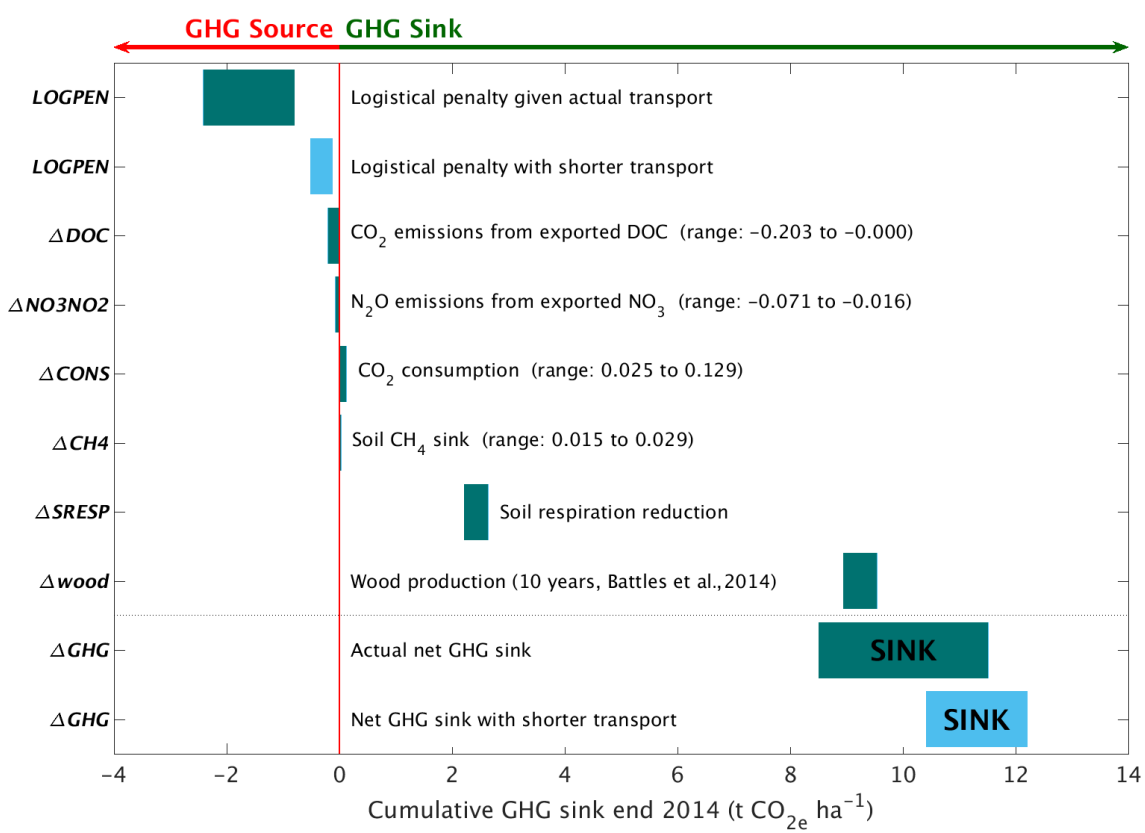

Figure 5. Carbon responses for the wollastonite treatment. Elements of the greenhouse gas balance associated with the wollastonite treatment (Table 4). The $\mathrm{CO}_{2}$ consumption range is given by $\mathrm{Wo}-\mathrm{CO}_{2, \mathrm{HCO}}$ calculated by Eq. (3) and $\mathrm{Wo}-\mathrm{CO}_{2, \mathrm{Ca}}$ calculated by Eq. (4), time-integrated from the application date through 2014. Nitrate export in stream water leading to $\mathrm{N}_{2} \mathrm{O}$ greenhouse gas emissions downstream and a small increase in the soil $\mathrm{CH}_{4}$ sink have been converted to $\mathrm{CO}_{2}$ equivalents (Methods). Exported DOC is assumed to be respired downstream.

We examined the potential $\mathrm{CO}_{2}$ consumption for a range of wollastonite application rates encompassing those suggested for ERW strategies (Strefler et al., 2018; Beerling et al., 2018) (Fig. 6). In this analysis, we adjusted mean (2003-2012) Wo- $\mathrm{CO}_{2, \mathrm{Ca}}$ for the actual $3.44 \mathrm{tha}^{-1}$ treatment $\left(\sim 0.2 \mathrm{~mol} \mathrm{C} \mathrm{m}^{-2} \mathrm{yr}^{-1}\right)$ proportionally for $10-50 \mathrm{tha}^{-1}$ treatments. We assume logistical carbon penalties are minimized and balanced by forest biomass carbon sequestration responses to treatment. This analysis suggests net CDR potential of $0.3-1.7 \mathrm{MtCO}_{2} \mathrm{yr}^{-1}$ along the Appalachian corridor, which is $2 \%-12 \%$ of New Hampshire state emissions $\left(13.8 \mathrm{MtCO}_{2}\right.$ ) in 2016 (Energy Information Administration, 2019). However, world wollastonite reserves (Curry, 2019) $(\geq 0.1 \mathrm{Pg})$ are insufficient to treat large areas of eastern North America at rates of $10-50 \mathrm{tha}^{-1}$, highlighting the requirement for alternative sustainable sources of silicate materials.

\section{Discussion}

Our analyses of wollastonite application at the HBEF provide a unique long-term (15 year) perspective on the whole watershed carbon cycle responses and net CDR by accounting for the associated $\mathrm{CO}_{2}$ costs of logistical operations. By 2015, net CDR amounted to $8.5-11.5 \mathrm{tCO}_{2} \mathrm{ha}^{-1}$ at a low rate of wollastonite application, with increased carbon sequestration into forest biomass playing the dominant role. We estimate that if the HBEF application rates were increased 10-fold, net CDR would increase by $8 \%$, assuming $400 \mathrm{~km}$ transport

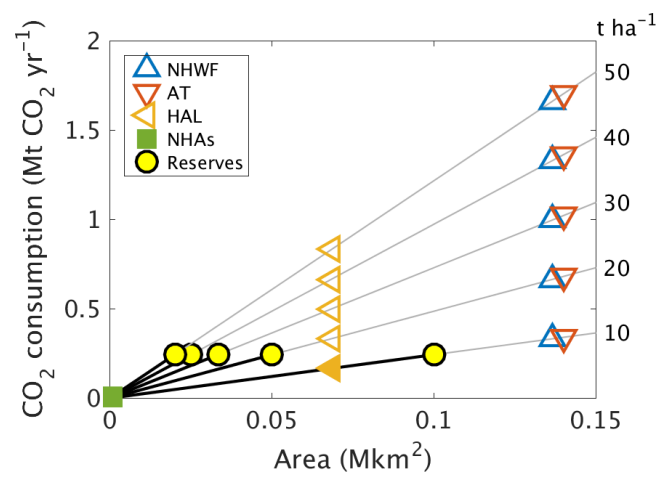

Figure 6. Projected $\mathrm{CO}_{2}$ consumption following higher-dosage treatments. We considered the possibility of higher-dosage silicate treatments on other northeastern United States higher-altitude forests affected by acid rain, such as Acer saccharum forests in New Hampshire (NHAs), the High Allegheny Plateau (HAL) ecoregion, the Appalachian trail corridor (AT), or northern hardwood forests (NHWFs) dominated by the same tree species as at Hubbard Brook. Because the world's wollastonite reserves (yellow discs) are insufficient to treat these areas, other calcium-rich silicate minerals would be required. $\mathrm{CO}_{2}$ consumption due to higher dosage $\left(\mathrm{tha}^{-1}\right.$ ) is estimated as (mean observed $\mathrm{CO}_{2, \mathrm{Ca}}$ between 2004 and 2012) $\times$ area $\times$ dosage $/ 3.44 \mathrm{tha}^{-1}$.

distances and no change in forest responses. Amplification of organic carbon capture may therefore represent a major CDR benefit of ERW when applied to forested lands affected by 
acid rain. Forest management practices, disturbance regimes, and the ultimate fate of any harvested wood are also important in determining the storage lifetime of the sequestered carbon. Our results highlight the need to carefully monitor the net carbon balance of forested ecosystems in response to a silicate treatment, including wood and canopy respiration (Fahey et al., 2005) (Methods). This challenging goal might best be achieved with fully instrumented eddy covariance plots, although the HBEF topography is not well suited for this approach (Fahey et al., 2005).

Inorganic $\mathrm{CO}_{2}$ consumption calculated based on streamwater bicarbonate fluxes approximately doubled in the treated watershed relative to the reference watershed 15 years post-treatment $\left(0.028\right.$ and $0.016 \mathrm{tCO}_{2} \mathrm{ha}^{-1}$ respectively) (Table 3). The presence of $\mathrm{SO}_{4}^{2-}, \mathrm{NO}_{3}^{-}$, and organic acid anions lowered the efficiency of $\mathrm{CO}_{2}$ consumption by alkalinity generation, with acid deposition having the single largest calculated effect (Table 3). The cause of increased $\mathrm{NO}_{3}^{-}$export from the treated watershed is not as yet understood (Rosi-Marshall et al., 2016). If it proves a general feature of terrestrial ecosystem responses to silicate mineral treatment, this could affect the efficiency of carbon capture via bicarbonate export. Overall, we suggest that continued recovery of eastern North American and European forests and soils from acid deposition creates conditions beneficial to watershed health, carbonic-acid-driven weathering, and inorganic carbon export following application of crushed silicate minerals.

In Asia, acid rain is an ongoing problem with an estimated $28 \%$ of Chinese land area $\left(\sim 2.7 \mathrm{Mkm}^{2}\right)$ receiving potentially damaging S deposition in 2005 (Zhao et al., 2009), and critical loads were exceeded in $\sim 0.36 \mathrm{Mkm}^{2}$ of the European Economic Area (EEA) in 1999 (Larssen et al., 2003), approximately double the affected area of US northern hardwood forests (Fig. 6). Figure 6 suggests that a single $30 \mathrm{t} \mathrm{Wo} \mathrm{ha}^{-1}$ treatment over $0.14 \mathrm{Mkm}^{2}$ (Appalachian Trail corridor) could, in principle, sequester $\sim 1 \mathrm{MtCO}_{2} \mathrm{yr}^{-1}$ or $15 \mathrm{MtCO}_{2}$ over 15 years via wollastonite-derived $\mathrm{Ca}$ export in stream water alone. Adding the Chinese and European acidified areas could potentially sequester $0.34 \mathrm{GtCO}_{2}$, approximately $0.2 \%-0.7 \%$ of the $\sim 50-150 \mathrm{Gt}$ CDR required by 2050 to avoid warming in excess of $1.5^{\circ}$ (Rogelj et al., 2018). Inclusion of biomass and soil responses increases CDR contributions from ERW on acidified forests, but these will still be modest. Assuming no further forest responses beyond the 15-year HBEF timeframe, we report a GHG balance of $\sim 10 \mathrm{tCO}_{2 \mathrm{e}} \mathrm{ha}^{-1}$. This translates to $1 \mathrm{GtCO}_{2 \mathrm{e}} \mathrm{Mkm}^{-2}$ suggesting $3.2 \mathrm{GtCO}_{2 \mathrm{e}}$ over 15 years for the Appalachian Trail, the EEA, and China combined, or $2 \%-6 \%$ of global required CDR as described above.

It is uncertain whether other acidified forest ecosystems would respond similarly to the HBEF Acer saccharum forests in New Hampshire. Many Chinese soils (Duan et al., 2016), as well as old deep soils in areas such as the Virginian Blue Ridge Mountains and the German Harz and Fichtel mountains (Garmo et al., 2014), have high $\mathrm{SO}_{4}^{2-}$ sorption capacity. These soils may retain substantially more $\mathrm{SO}_{4}^{2-}$ than the HBEF soils, with potential for prolonged $\mathrm{SO}_{4}^{2-}$ flushing following ERW treatment and lower bicarbonate production. Liming studies suggest a range of other effects, some of which may also occur with silicate treatments. Liming increases nitrate export, migration of heavy metals and acidity to deeper soil, and fine root production in topsoils leading to frost damage (Huettl and Zoettl, 1993).

Many forests have been limed with carbonate minerals such as calcite and dolomite to mitigate acidification in the past. Dolomite has also helped reverse $\mathrm{Mg}$ deficiency in conifers (Huettl and Zoettl, 1993). Liming generally improves water quality, although it also forms mixing zones with high-molecular-weight Al complexes toxic to fish (Teien et al., 2006). With silicate treatments, nontoxic hydroxyaluminosilicates form instead (Teien et al., 2006). Unfortunately, carbonates are contraindicated for CDR on acid soils because they can be a net source of $\mathrm{CO}_{2}$ in the presence of strong acids (Hamilton et al., 2007). Treatments of European and North American acidified forests with calcite (1$\left.18 \mathrm{tha}^{-1} \mathrm{CaCO}_{3}\right)$ or dolomite $\left(2-8.7 \mathrm{tha}^{-1} \mathrm{CaMg}\left(\mathrm{CO}_{3}\right)_{2}\right)$ have, in general, resulted in increased DOC export and soil respiration without increasing tree growth, regardless of forest composition (Lundström et al., 2003). As calcite and dolomite are $44 \%$ and $48 \% \mathrm{CO}_{2}$ by weight, these treatments will have released $0.44-7.9$ and $0.96-4.54 \mathrm{tCO}_{2} \mathrm{ha}^{-1}$ respectively when fully dissolved, although dissolution may be slow. Over 6 years following a $2.9 \mathrm{tdolomite} \mathrm{ha}^{-1}$ treatment $(90 \% 0.2-2.0 \mathrm{~mm}$ grains) in a Norwegian coniferous watershed equating to $1.36 \mathrm{tCO}_{2} \mathrm{ha}^{-1}$, less than $1 \%$ of the dolomite dissolved (Hindar et al., 2003). We estimate that $\mathrm{CO}_{2}$ consumption corrected for $\mathrm{CO}_{2}$ release and as measured with dolomite-derived $\mathrm{Ca}$ and $\mathrm{Mg}$ in stream water (Dol- $\mathrm{CO}_{2, \mathrm{Ca}+\mathrm{Mg}}$ ) averaged $0.02 \mathrm{~mol} \mathrm{CO}_{2} \mathrm{~m}^{-2} \mathrm{yr}^{-1} \cdot \mathrm{CO}_{2}$ release from carbonate minerals equals $\mathrm{Ca}$ and $\mathrm{Mg}$ release on a molar basis, so $0.02 \mathrm{~mol}$ Dol- $\mathrm{CO}_{2} \mathrm{~m}^{-2} \mathrm{yr}^{-1}$ was also either exported in stream water or lost to the atmosphere. This experiment may have a negative greenhouse gas balance depending on logistical penalties and soil respiration, as there was no significant treatment effect on tree growth or vitality (Hindar et al., 2003). Ca-sensitive Acer saccharum is present at Woods Lake in New York state, yet tree biomass decreased with no significant differences relative to reference catchments during the 20 years following a $6.89 \mathrm{t} \mathrm{Mg-}$ calcite $\mathrm{ha}^{-1}$ application (Melvin et al., 2013), equivalent to $3.07 \mathrm{tCO}_{2} \mathrm{ha}^{-1}$ given $8 \% \mathrm{Mg}$ content of the pellets. In contrast to our study and other liming studies, root biomass and soil carbon stocks increased in response to this treatment, although soil respiration was reduced (Melvin et al., 2013). Acer saccharum basal area and crown vigour increased over 23 years in response to $22.4 \mathrm{t}$ dolomitic limestone $\mathrm{ha}^{-1}$ (equivalent to $10.0 \mathrm{tCO}_{2} \mathrm{ha}^{-1}$ ) on the Allegheny Plateau, although basal area and survival of another domi- 
nant canopy species, Prunus serotina, was reduced (Long et al., 2011). Clearly, forest responses to mineral treatments are species- and site-specific.

Although the HBEF experiment used wollastonite, this is not a target mineral for ERW, because of both its limited reserves (Curry, 2019) and high monetary costs (Schlesinger and Amundson, 2018). Recent all-inclusive guide prices of $\sim$ USD $700 \mathrm{Mg}^{-1}$ for helicopter deployment of pelletized lime along the Appalachian Mountain corridor are comparable to the price of USD $694 \mathrm{Mg}^{-1}$ for unpelletized $10 \mu \mathrm{m}$ wollastonite in 2000 (Virta, 2000). Less expensive materials such as locally sourced waste fines from mines or volcanic ash (Longman et al., 2020) should be considered if their heavy metal content is low, but the choice of treatment material should be considered together with the vegetation and the native minerals. Application of magnesium-rich materials (e.g. olivine), for example, may help reverse $\mathrm{Mg}$ deficiency in Pinus sylvatica and Picea abies as dolomite has done (Huettl and Zoettl, 1993), but some other tree species, such as Acer saccharum, have a higher demand for calcium than for magnesium (Long et al., 2009). The treatment of ecologically sensitive catchments always requires caution as some species, such as Sphagnum mosses and lichens, may respond poorly to treatment (Traaen et al., 1997).

Finally, we consider integration of ERW treatments with forest management practices. Dominant CDR pathways depend on biogeochemical cycling which in turn depends on the life cycle of the dominant trees. For example, base cation export and therefore $\mathrm{CO}_{2}$ consumption temporarily increases following clear-felling, then decreases while trees are young and growing due to base cation uptake, and remains low after trees mature due to nutrient recycling (Balogh-Brunstad et al., 2008). These dynamics may be less obvious in forests which are not clear-felled; Acer saccharum forests are often thinned and retain a canopy as the seedlings are adapted to shade. Individual Acer saccharum trees can live for over 300 years, growing relatively slowly for the first 40 years and attaining maximum height during the first 150 years (Godman et al., 1990). One may expect to maximize wood production of growing trees with ERW treatments meeting or exceeding the forest demand for previously limited nutrients such as calcium, which would also minimize soil respiration if the trees allocate less carbon to roots. Treatments could be repeated as necessary to meet the nutritional needs of sensitive trees or to maintain high $\mathrm{CO}_{2}$ consumption. Conversely, rising soil $\mathrm{pH}$ may not suit some species. For example, Acer saccharum normally grows in organic-rich soils with $\mathrm{pH}$ under 7.3 (Godman et al., 1990) and its growth may be hindered at higher $\mathrm{pH}$ following large treatments. Outside the main tree growth phase, and in forests without responsive tree species, $\mathrm{CO}_{2}$ consumption could become the dominant GHG response to ERW treatments depending on the extent to which it is counteracted by DOC export as soil $\mathrm{pH}$ rises (Johnson et al., 2014) and decomposition rates and fluxes rise (Lovett et al., 2016). Site-specific research is required to de- termine the optimum dosage, timing, efficacy, and suitability of ERW treatments on acid-impacted forests. 


\section{Appendix A: Contributions of rain and snow precipitation to stream-water chemistry}

We estimated the contribution of rain and snow (Likens, $2016 \mathrm{~b}$, a) relative to all other sources using a previously published mixing model (Négrel et al., 1993). We assume all $\mathrm{Cl}^{-}$ in the water is from rain and snow, noting however that this common treatment of $\mathrm{Cl}$ as an unreactive tracer is not always justified (Lovett et al., 2005). We calculate the contribution of precipitation to the stream water $\left(\alpha_{\text {rain }}\right)$ using $\mathrm{Na}$ and $\mathrm{Cl}$, which are less affected by nutrient cycling and adsorption than other major ions (Négrel et al., 1993):

$\alpha_{\text {rain, Na }}(t)=\frac{\left[\frac{\mathrm{Cl}}{\mathrm{Na}}\right](\text { stream }, t)}{\left[\frac{\mathrm{Cl}}{\mathrm{Na}}\right](\text { rain }, t)}$.

To account for attenuation of the rain and snow precipitation leaching through the soil, $\mathrm{Cl} / \mathrm{Na}$ and $\mathrm{HCO}_{3} / \mathrm{Na}$ at any given time $(t)$ are means from the previous 3 months. We estimate the contribution of rain and snow to other ions such as $\mathrm{HCO}_{3}^{-}$ in the stream water as follows:

$\alpha_{\text {rain, } \mathrm{HCO}_{3}}(t)=\alpha_{\text {rain }, \mathrm{Na}}(t) \times \frac{\left[\frac{\mathrm{HCO}_{3}}{\mathrm{Na}}\right](\text { stream }, t)}{\left[\frac{\mathrm{HCO}}{\mathrm{Na}}\right](\text { rain }, t)}$.

\section{Appendix B: Fraction of calcium derived from wollastonite}

We applied an existing two-component mixing model (Peters et al., 2004):

$$
\begin{aligned}
& X_{\mathrm{Ca}}(t)= \\
& {\left[\frac{\left(\left(\frac{87 \mathrm{Sr}}{86 \mathrm{Sr}}\right)_{\mathrm{post}}-\left(\frac{87 \mathrm{Sr}}{86 \mathrm{Sr}}\right)_{\mathrm{pre}}\right)\left(\frac{\mathrm{Sr}}{\mathrm{Ca}}\right)_{\mathrm{pre}}}{\left(\left(\frac{87 \mathrm{Sr}}{86 \mathrm{Sr}}\right)_{\mathrm{post}}-\left(\frac{87 \mathrm{Sr}}{86 \mathrm{Sr}}\right)_{\mathrm{pre}}\right)\left(\frac{\mathrm{Sr}}{\mathrm{Ca}}\right)_{\mathrm{pre}}+\left(\left(\frac{87 \mathrm{Sr}}{86 \mathrm{Sr} r}\right)_{\mathrm{Wo}}-\left(\frac{87 \mathrm{Sr}}{{ }^{60} \mathrm{Sr}}\right)_{\mathrm{pre}}\right)\left(\frac{\mathrm{Sr}}{\mathrm{Ca}}\right)_{\mathrm{Wo}}}\right],}
\end{aligned}
$$

where pre-app and post-app refer to pre-application and postapplication stream-water concentrations and Wo refers to wollastonite. The Sr data (Blum, 2019) have been extended through 2015 (Fig. S1a). See Supplement for further discussion of the use of strontium and its isotopes as tracers of $\mathrm{Ca}^{2+}$ provenance. 
Code availability. Our MATLAB code and scripts used for this project are provided in the Supplement, without any guarantees whatsoever.

Data availability. Our data are available from the Long Term Ecological Research (LTER) Network Data Portal. This public repository can be accessed via the Hubbard Brook Ecosystem Study website: https://hubbardbrook.org/d/hubbard-brook-data-catalog (last access: July 2019). The data include chemistry data for treated and reference watersheds (https://doi.org/10.6073/pasta/ fcfa498c5562ee55f6e84d7588a980d2, Driscoll, 2016a; https: //doi.org/10.6073/pasta/0033e820ff0e6a055382d4548dc5c90c,

Driscoll, 2016b), precipitation chemistry data for treated and reference watersheds (https://doi.org/10.6073/pasta/ 8d2d88dc718b6c5a2183cd88aae26fb1, Likens, 2016a; https: //doi.org/10.6073/pasta/df90f97d15c28daeb7620b29e2384bb9,

Likens, 2016b), trace gas flux data (https://doi.org/10. 6073/pasta/9d017f1a32cba6788d968dc03632ee03, Groffman, 2016), forest inventory data for 2006 and 2011 (https: //doi.org/10.6073/pasta/94f9084a3224c1e3e0ed38763f8dae02,

Battles et al., 2015a; https://doi.org/10.6073/pasta/ 37c5a5868158e87db2d30c2d62a57e14, Battles et al., 2015b) and for 1999 and 2001 (https://doi.org/10.6073/pasta/ a2300121b6d594bbfcb3256ca1c300c8, Driscoll et al., 2015a; https: //doi.org/10.6073/pasta/9ff720ba22aef2b40fc5d9a7b374aa52,

Driscoll et al., 2015b), streamflow data (https://doi.org/10. 6073/pasta/727ee240e0b1e10c92fa28641bedb0a3, Campbell, 2015), $\mathrm{Sr}$ isotope data (https://doi.org/10.6073/ pasta/43ebc0f959780cfc30b7ad53cc4a3d3e, Blum, 2019), and air temperature data (https://doi.org/10.6073/pasta/ 75b416d670de920c5ace92f8f3182964, Campbell, 2016). See Supplement for a full list of filenames, package IDs, DOIs, and access dates.

Supplement. The supplement related to this article is available online at: https://doi.org/10.5194/bg-18-169-2021-supplement.

Author contributions. All authors contributed to project conceptualization and interpretation of model results. LLT undertook model simulations and data analysis. LLT and DJB drafted the manuscript with edits and revisions from all authors. CTD designed the wollastonite watershed study and provided data and observations for model simulations. JDB provided strontium isotope datasets. PMG provided soil respiration, nitrous oxide, and methane flux data. GHR contributed to project conceptualization and edited the manuscript.

Competing interests. The authors declare that they have no conflict of interest.

Acknowledgements. Lyla L. Taylor and David J. Beerling gratefully acknowledge funding from the Leverhulme Trust through a Leverhulme Research Centre Award (RC-2015-029). This paper is a contribution of the Hubbard Brook Ecosystem Study. Hubbard Brook is part of the Long-Term Ecological Research (LTER) network, which is supported by the National Science Foundation (DEB-1633026). Lyla L. Taylor thanks Ruth Yanai for a helpful discussion about vegetation, Fred Worrall for advice on flow adjustment and flux calculation, Peter Wade for advice on the initial PHREEQC setup, and Andrew Beckerman and Evan DeLucia for constructive criticism and advice on statistical modelling. We are grateful to Gregory Lawrence for information about applying lime treatments to the Appalachian Trail corridor, to Lisa Martel for providing the locations of the trace gas sampling sites, and to Habibollah Fahkraei for creating the watershed map with weir and trace gas sampling locations in Fig. 1. We are grateful for comments from W. Brian Whalley and editor Tyler Cyronak and for reviews from Morgan Jones and the anonymous referee which led to major improvements in this paper.

Financial support. This research has been supported by the Leverhulme Trust (grant no. RC-2015-029) and the National Science Foundation (DEB-1633026).

Review statement. This paper was edited by Tyler Cyronak and reviewed by Morgan Jones and one anonymous referee.

\section{References}

Bailey, S., Horsley, S., Long, R., and Hallett, R.: Influence of edaphic factors on sugar maple nutrition and health on the Allegheny Plateau, Soil Sci. Soc. Am. J., 68, 243-252, 2004.

Balogh-Brunstad, Z., Keller, C. K., Bormann, B. T., O'Brien, R., Wang, D., and Hawley, G.: Chemical weathering and chemical denudation dynamics through ecosystem development and disturbance, Global Biogeochem. Cy., 22, GB1007, https://doi.org/10.1029/2007GB002957, 2008.

Battles, J. J., Fahey, T. J., Driscoll Jr., C. T., Blum, J. D., and Johnson, C. E.: Restoring soil calcium reverses forest decline, Environ. Sci. Technol. Lett., 1, 15-19, 2014.

Battles, J. J., Driscoll Jr., C. T., Bailey, S. W., Blum, J. D., Buso, D. C., Fahey, T. J., Fisk, M., Groffman, P. M., Johnson, C., and Likens, G.: Forest Inventory of a Calcium Amended Northern Hardwood Forest: Watershed 1, 2011, Hubbard Brook Experimental Forest, Environmental Data Initiative, https://doi.org/10. 6073/pasta/94f9084a3224c1e3e0ed38763f8dae02, 2015a.

Battles, J. J., Driscoll Jr., C. T., Bailey, S. W., Blum, J. D., Buso, D. C., Fahey, T. J., Fisk, M., Groffman, P. M., Johnson, C., and Likens, G.: Forest Inventory of a Calcium Amended Northern Hardwood Forest: Watershed 1, 2006, Hubbard Brook Experimental Forest, Environmental Data Initiative, https://doi.org/10. 6073/pasta/37c5a5868158e87db2d30c2d62a57e14, $2015 \mathrm{~b}$.

Beerling, D. J., Leake, J. R., Long, S. P., Scholes, J. D., Ton, J., Nelson, P. N., Bird, M., Kantzas, E., Taylor, L. L., and Sarkar, B.: Farming with crops and rocks to address global climate, food and soil security, Nat. Plants, 4, 138-147, 2018.

Blum, J. D.: Streamwater Ca, Sr and ${ }^{87} \mathrm{Sr} /{ }^{86} \mathrm{Sr}$ measurements on Watershed 1 at the Hubbard Brook Experimental Forest, Environmental Data Initiative, https://doi.org/10.6073/pasta/ 43ebc0f959780cfc30b7ad53cc4a3d3e, 2019. 
Blum, J. D., Klaue, A., Nezat, C. A., Driscoll, C. T., Johnson, C. E., Siccama, T. G., Eagar, C., Fahey, T. J., and Likens, G. E.: Mycorrhizal weathering of apatite as an important calcium source in base-poor forest ecosystems, Nature, 417, 729-731, 2002.

Brantley, S. L., Kubicki, J. D., and White, A. F.: Kinetics of waterrock interaction, Springer, New York, USA, 2008.

Campbell, J.: Hubbard Brook Experimental Forest (USDA Forest Service): Daily Streamflow by Watershed, 1956-present, Environmental Data Initiative, https://doi.org/10.6073/pasta/ 727ee240e0b1e10c92fa28641bedb0a3, 2015.

Campbell, J.: Hubbard Brook Experimental Forest (USDA Forest Service): Daily Mean Temperature Data, 1955-present, Environmental Data Initiative, https://doi.org/10.6073/pasta/ 75b416d670de920c5ace92f8f3182964, 2016.

Campbell, J. L., Driscoll, C. T., Eagar, C., Likens, G. E., Siccama, T. G., Johnson, C. E., Fahey, T. J., Hamburg, S. P., Holmes, R. T., and Bailey, A. S.: Long-term trends from ecosystem research at the Hubbard Brook Experimental Forest, Gen. Tech. Rep. NRS17, US Department of Agriculture, Forest Service, Northern Research Station, Newtown Square, PA, USA, 41 p., 2007.

Campbell, J. L., Rustad, L. E., Boyer, E. W., Christopher, S. F., Driscoll, C. T., Fernandez, I. J., Groffman, P. M., Houle, D., Kiekbusch, J., and Magill, A. H.: Consequences of climate change for biogeochemical cycling in forests of northeastern North America, Can. J. Forest Res., 39, 264-284, 2009.

Cawley, K. M., Campbell, J., Zwilling, M., and Jaffé, R.: Evaluation of forest disturbance legacy effects on dissolved organic matter characteristics in streams at the Hubbard Brook Experimental Forest, New Hampshire, Aquat. Sci., 76, 611-622, 2014.

Chetelat, B., Liu, C.-Q., Zhao, Z., Wang, Q., Li, S., Li, J., and Wang, B.: Geochemistry of the dissolved load of the Changjiang Basin rivers: anthropogenic impacts and chemical weathering, Geochim. Cosmochim. Ac., 72, 4254-4277, 2008.

Cho, Y., Driscoll, C. T., Johnson, C. E., Blum, J. D., and Fahey, T. J.: Watershed-level responses to calcium silicate treatment in a northern hardwood forest, Ecosystems, 15, 416-434, 2012.

Curry, K. C.: Mineral Commodity Summaries: Wollastonite, available at: https://www.usgs.gov/centers/nmic/ wollastonite-statistics-and-information, last access: 11 September 2019.

De Klein, C., Novoa, R. S. A., Ogle, S., Smith, K. A., Rochette, P., Wirth, T. C., McConkey, B. G., Mosier, A., and Rypdal, K.: $\mathrm{N}_{2} \mathrm{O}$ emissions from managed soils, and $\mathrm{CO}_{2}$ emissions from lime and urea application, in: 2006 IPCC Guidelines for National Greenhouse Gas Inventories, Vol 4: Agriculture, Forestry and Other Land Use, edited by: Eggleston, S., Buendia, L., Miwa, K., Ngara, T., and Tanabe, K., Institute for Global Environmental Strategies (IGES), Intergovernmental Panel on Climate Change (IPPC), Kanagawa, Japan, 11.11-11.54, 2006.

Driscoll, C. T.: Longitudinal Stream Chemistry at the Hubbard Brook Experimental Forest, Watershed 1, 1991-present, Environmental Data Initiative, https://doi.org/10.6073/pasta/ fcfa498c5562ee55f6e84d7588a980d2, 2016a.

Driscoll, C. T.: Longitudinal Stream Chemistry at the Hubbard Brook Experimental Forest, Watershed 6, 1982-present, Environmental Data Initiative, https://doi.org/10.6073/pasta/ 0033e820ff0e6a055382d4548dc5c90c, 2016b.

Driscoll, C. T., Bailey, S. W., Blum, J. D., Buso, D. C., Eagar, C., Fahey, T. J., Fisk, M., Groffman, P. M., Johnson,
C., Likens, G., Hamburg, S. P., and Siccama, T. G.: Forest Inventory of a Calcium Amended Northern Hardwood Forest: Watershed 1, 2001, Hubbard Brook Experimental Forest, Environmental Data Initiative, https://doi.org/10.6073/pasta/ a2300121b6d594bbfcb3256ca1c300c8, 2015a.

Driscoll Jr., C. T., Bailey, S. W., Blum, J. D., Buso, D. C., Eagar, C., Fahey, T. J., Fisk, M., Groffman, P. M., Johnson, C., Likens, G., Hamburg, S. P., and Siccama, T. G.: Forest Inventory of a Calcium Amended Northern Hardwood Forest: Watershed 1, 1996, Hubbard Brook Experimental Forest. Environmental Data Initiative, https://doi.org/10.6073/pasta/ 9ff720ba22aef2b40fc5d9a7b374aa52, 2015b.

Duan, L., Yu, Q., Zhang, Q., Wang, Z., Pan, Y., Larssen, T., Tang, J., and Mulder, J.: Acid deposition in Asia: emissions, deposition, and ecosystem effects, Atmos. Environ., 146, 55-69, https://doi.org/10.1016/j.atmosenv.2016.07.018, 2016.

Energy Information Administration: Inventory of Power Plants in the United States, United States Department of Energy, Washington, DC, USA, DCDOE/EIA-0095(97), 431 pp., 1997.

Energy Information Administration: Energy-Related Carbon Dioxide Emissions by State, 2005-2016, United States Department of Energy, Washington, D.C. 20585, USA, 34 pp., 2019.

Fahey, T., Siccama, T., Driscoll, C., Likens, G., Campbell, J., Johnson, C., Battles, J., Aber, J., Cole, J., and Fisk, M.: The biogeochemistry of carbon at Hubbard Brook, Biogeochemistry, 75, 109-176, 2005.

Fahey, T. J., Heinz, A. K., Battles, J. J., Fisk, M. C., Driscoll, C. T., Blum, J. D., and Johnson, C. E.: Fine root biomass declined in response to restoration of soil calcium in a northern hardwood forest, Can. J. Forest Res., 46, 738-744, 2016.

Fakhraei, H. and Driscoll, C. T.: Proton and aluminum binding properties of organic acids in surface waters of the northeastern US, Environ. Sci. Technol., 49, 2939-2947, https://doi.org/10.1021/es504024u, 2015.

Fakhraei, H., Driscoll, C. T., Renfro, J. R., Kulp, M. A., Blett, T. F., Brewer, P. F., and Schwartz, J. S.: Critical loads and exceedances for nitrogen and sulfur atmospheric deposition in Great Smoky Mountains National Park, United States, Ecosphere, 7, e01466, https://doi.org/10.1002/ecs2.1466, 2016.

Ferree, C. and Anderson, M. G.: A map of terrestrial habitats of the Northeastern United States: methods and approach, Nature Conservancy, Eastern Conservation Science, Eastern Regional Office, Boston, USA, 2013.

Fuller, R., Driscoll, C., Lawrence, G., and Nodvin, S.: Processes regulating sulphate flux after whole-tree harvesting, Nature, 325, 707-710, 1987.

Garmo, Ø. A., Skjelkvåle, B. L., de Wit, H. A., Colombo, L., Curtis, C., Fölster, J., Hoffmann, A., Hruška, J., Høgåsen, T., and Jeffries, D. S.: Trends in surface water chemistry in acidified areas in Europe and North America from 1990 to 2008, Water Air Soil Poll., 225, 1880, https://doi.org/10.1007/s11270-014-18806, 2014.

Godman, R. M., Yawney, H. W., and Tubbs, C. H.: Acer saccharum Marsh. sugar maple, in: Silvics of North America Volume 2, Agriculture Handbook 654, tech. coords. Burns, R. M. and Honkala, B. H., United States Department of Agriculture, Forest Service, Washington, D.C., USA, 1990. 
Goodale, C. L. and Aber, J. D.: The long-term effects of land-use history on nitrogen cycling in northern hardwood forests, Ecol. Appl., 11, 253-267, 2001.

Groffman, P. M.: Forest soil: atmosphere fluxes of carbon dioxide, nitrous oxide and methane at the Hubbard Brook Experimental Forest, 1997-present, Environmental Data Initiative, https://doi. org/10.6073/pasta/9d017f1a32cba6788d968dc03632ee03, 2016.

Groffman, P. M., Fisk, M. C., Driscoll, C. T., Likens, G. E., Fahey, T. J., Eagar, C., and Pardo, L. H.: Calcium additions and microbial nitrogen cycle processes in a northern hardwood forest, Ecosystems, 9, 1289-1305, 2006.

Hamilton, S. K., Kurzman, A. L., Arango, C., Jin, L., and Robertson, G. P.: Evidence for carbon sequestration by agricultural liming, Global Biogeochem. Cy., 21, GB2021, https://doi.org/10.1029/2006GB002738, 2007.

Harrison, R. B., Johnson, D. W., and Todd, D. E.: Sulfate adsorption and desorption reversibility in a variety of forest soils, J. Environ. Qual., 18, 419-426, 1989.

Hartmann, J., West, A. J., Renforth, P., Köhler, P., Christina, L., Wolf-Gladrow, D. A., Dürr, H. H., and Scheffran, J.: Enhanced chemical weathering as a geoengineering strategy to reduce atmospheric carbon dioxide, supply nutrients, and mitigate ocean acidification, Rev. Geophys., 51, 113-149, 2013.

Hindar, A., Wright, R. F., Nilsen, P., Larssen, T., and Høgberget, R.: Effects on stream water chemistry and forest vitality after whole-catchment application of dolomite to a forest ecosystem in southern Norway, Forest Ecol. Manag., 180, 509-525, 2003.

$\mathrm{Hu}, \mathrm{M}$., Chen, D., and Dahlgren, R. A.: Modeling nitrous oxide emission from rivers: a global assessment, Glob. Change Biol., 22, 3566-3582, 2016.

Huettl, R. F. and Zoettl, H.: Liming as a mitigation tool in Germany's declining forests - reviewing results from former and recent trials, Forest Ecol. Manag., 61, 325-338, 1993.

Jacobson, A. D. and Blum, J. D.: Relationship between mechanical erosion and atmospheric $\mathrm{CO}_{2}$ consumption in the New Zealand Southern Alps, Geology, 31, 865-868, 2003.

Johnson, C. E., Driscoll, C. T., Blum, J. D., Fahey, T. J., and Battles, J. J.: Soil chemical dynamics after calcium silicate addition to a northern hardwood forest, Soil Sci. Soc. Am. J., 78, 1458-1468, 2014.

Johnson, N. M., Driscoll, C. T., Eaton, J. S., Likens, G. E., and McDowell, W. H.: "Acid rain", dissolved aluminum and chemical weathering at the Hubbard Brook Experimental Forest, New Hampshire, Geochim. Cosmochim. Ac., 45, 1421-1437, 1981.

Köhler, S., Laudon, H., Wilander, A., and Bishop, K.: Estimating organic acid dissociation in natural surface waters using total alkalinity and TOC, Water Res., 34, 1425-1434, 2000.

Larssen, S., Barrett, K. J., Fiala, J., Goodwin, J., Hagen, L. O., Henriksen, J. F., de Leeuw, F., Tarrason, L., and van Aalst, R.: Air quality in Europe: State and trends 1990-99, No. 4-2002, European Environment Agency, Copenhagen, Denmark, 2003.

Lawrence, G., Sullivan, T., Burns, D., Bailey, S., Cosby, B., Dovciak, M., Ewing, H., McDonnel, T., Minocha, R., and Rice, K.: Acidic deposition along the Appalachian Trail corridor and its effects on acid-sensitive terrestrial and aquatic resources: results of the Appalachian Trail MEGA-transect atmospheric deposition effects study, National Park Service, Fort Collins, Colorado, USA, 2015.
Likens, G. E.: Chemistry of Bulk Precipitation at Hubbard Brook Experimental Forest, Watershed 6, 1963-present, Environmental Data Initiative, https://doi.org/10.6073/pasta/ 8d2d88dc718b6c5a2183cd88aae26fb1, 2016a.

Likens, G. E.: Chemistry of Bulk Precipitation at Hubbard Brook Experimental Forest, Watershed 1, 1963-present, Environmental Data Initiative, https://doi.org/10.6073/pasta/ df90f97d15c28daeb7620b29e2384bb9, 2016b.

Likens, G. E.: Biogeochemistry of a forested ecosystem, 3rd edn., Springer Science \& Business Media, New York, USA, 208 pp., 2013.

Likens, G. E. and Bailey, S. W.: The discovery of acid rain at the Hubbard Brook Experimental Forest: a story of collaboration and long-term research, in: USDA Forest Service Experimental Forests and Ranges, Springer, New York, USA, 463-482, 2014.

Likens, G. E., Buso, D. C., Dresser, B. K., Bernhardt, E. S., Hall Jr., R. O., Macneale, K. H., and Bailey, S. W.: Buffering an acidic stream in New Hampshire with a silicate mineral, Restor. Ecol., 12, 419-428, 2004.

Littlewood, I., Watts, C., and Custance, J.: Systematic application of United Kingdom river flow and quality databases for estimating annual river mass loads (1975-1994), Sci. Total Environ., 210, 21-40, 1998.

Long, R. P., Horsley, S. B., Hallett, R. A., and Bailey, S. W.: Sugar maple growth in relation to nutrition and stress in the northeastern United States, Ecol. Appl., 19, 1454-1466, 2009.

Long, R. P., Horsley, S. B., and Hall, T. J.: Long-term impact of liming on growth and vigor of northern hardwoods, Can. J. Forest Res., 41, 1295-1307, 2011.

Longman, J., Palmer, M. R., and Gernon, T. M. J. A.: Viability of greenhouse gas removal via the artificial addition of volcanic ash to the ocean, Anthropocene, 32, 100264, https://doi.org/10.1016/j.ancene.2020.100264, 2020.

Lovett, G. M., Likens, G. E., Buso, D. C., Driscoll, C. T., and Bailey, S. W.: The biogeochemistry of chlorine at Hubbard Brook, New Hampshire, USA, Biogeochemistry, 72, 191-232, 2005.

Lovett, G. M., Arthur, M. A., and Crowley, K. F.: Effects of calcium on the rate and extent of litter decomposition in a northern hardwood forest, Ecosystems, 19, 87-97, 2016.

Lundström, U., Bain, D., Taylor, A., and Van Hees, P.: Effects of acidification and its mitigation with lime and wood ash on forest soil processes: a review, Water, Air and Soil Pollution: Focus, 3, 5-28, 2003.

Martin, A. R., Doraisami, M., and Thomas, S. C.: Global patterns in wood carbon concentration across the world's trees and forests, Nat. Geosci., 11, 915-920, https://doi.org/10.1038/s41561-0180246-x, 2018.

McLauchlan, K. K., Craine, J. M., Oswald, W. W., Leavitt, P. R., and Likens, G. E.: Changes in nitrogen cycling during the past century in a northern hardwood forest, P. Natl. Acad. Sci. USA, 104, 7466-7470, 2007.

Melvin, A. M., Lichstein, J. W., and Goodale, C. L.: Forest liming increases forest floor carbon and nitrogen stocks in a mixed hardwood forest, Ecol. Appl., 23, 1962-1975, 2013.

Mohseni, O. and Stefan, H.: Stream temperature/air temperature relationship: a physical interpretation, J. Hydrol., 218, 128-141, 1999. 
Moon, S., Chamberlain, C., and Hilley, G.: New estimates of silicate weathering rates and their uncertainties in global rivers, Geochim. Cosmochim. Ac., 134, 257-274, 2014.

Moosdorf, N., Renforth, P., and Hartmann, J.: Carbon dioxide efficiency of terrestrial enhanced weathering, Environ. Sci. Technol., 48, 4809-4816, 2014.

Négrel, P., Allègre, C. J., Dupré, B., and Lewin, E.: Erosion sources determined by inversion of major and trace element ratios and strontium isotopic ratios in river water: the Congo Basin case, Earth Planet. Sc. Lett., 120, 59-76, 1993.

Nezat, C. A., Blum, J. D., and Driscoll, C. T.: Patterns of $\mathrm{Ca} / \mathrm{Sr}$ and ${ }^{87} \mathrm{Sr} /{ }^{86} \mathrm{Sr}$ variation before and after a whole watershed $\mathrm{CaSiO}_{3}$ addition at the Hubbard Brook Experimental Forest, USA, Geochim. Cosmochim. Ac., 74, 3129-3142, https://doi.org/10.1016/j.gca.2010.03.013, 2010.

Pachauri, R. K., Allen, M. R., Barros, V. R., Broome, J., Cramer, W., Christ, R., Church, J. A., Clarke, L., Dahe, Q., and Dasgupta, P.: Climate change 2014: synthesis report. Contribution of Working Groups I, II and III to the fifth assessment report of the Intergovernmental Panel on Climate Change, IPCC, Geneva, Switzerland, 2014.

Parkhurst, D. L. and Appelo, C.: User's guide to PHREEQC (Version 2): A computer program for speciation, batch-reaction, onedimensional transport, and inverse geochemical calculations, US Geological Survey, Denver, USA, 326 pp., 1999.

Peters, S. C., Blum, J. D., Driscoll, C. T., and Likens, G. E.: Dissolution of wollastonite during the experimental manipulation of Hubbard Brook Watershed 1, Biogeochemistry, 67, 309-329, https://doi.org/10.1023/B:BIOG.0000015787.44175.3f, 2004.

Renforth, P.: The potential of enhanced weathering in the UK, Int. J. Greenh. Gas Con., 10, 229-243, 2012.

Rogelj, J., Shindell, D., Jiang, K., Fifita, S., Forster, P., Ginzburg, V., Handa, C., Kheshgi, H., Kobayashi, S., Kriegler, E., Mundaca, L., Séférian, R., and Vilariño, M.: Mitigation Pathways Compatible with $1.5^{\circ} \mathrm{C}$ in the Context of Sustainable Development, in: Global Warming of $1.5^{\circ} \mathrm{C}$, an IPCC special report on the impacts of global warming of $1.5^{\circ} \mathrm{C}$ above pre-industrial levels and related global greenhouse gas emission pathways, in the context of strengthening the global response to the threat of climate change, Intergovernmental Panel on Climate Change, available at: https://www.ipcc.ch/site/assets/uploads/sites/2/2019/05/ SR15_Chapter2_Low_Res.pdf (last access: 18 October 2019), 2018.

Rosi-Marshall, E. J., Bernhardt, E. S., Buso, D. C., Driscoll, C. T., and Likens, G. E.: Acid rain mitigation experiment shifts a forested watershed from a net sink to a net source of nitrogen, $\mathrm{P}$. Natl. Acad. Sci. USA, 113, 7580-7583, 2016.

Schaberg, P. G., Miller, E. K., and Eagar, C.: Assessing the threat that anthropogenic calcium depletion poses to forest health and productivity, US Department of Agriculture, Forest Service, Pacific Northwest and Southern Research Stations, Portland, OR, USA, 37-58, 2010.

Schlesinger, W. H. and Amundson, R.: Managing for soil carbon sequestration: Let's get realistic, Glob. Change Biol., 25, 386389, https://doi.org/10.1111/gcb.14478, 2018.
Sebestyen, S. D., Boyer, E. W., and Shanley, J. B.: Responses of stream nitrate and DOC loadings to hydrological forcing and climate change in an upland forest of the northeastern United States, J. Geophys. Res.-Biogeo., 114, G02002, https://doi.org/10.1029/2008JG000778, 2009.

Shao, S., Driscoll, C. T., Johnson, C. E., Fahey, T. J., Battles, J. J., and Blum, J. D.: Long-term responses in soil solution and streamwater chemistry at Hubbard Brook after experimental addition of wollastonite, Environ. Chem, 13, 528-540, 2016.

Sims, R., Schaeffer, R., Creutzig, F., Cruz-Núñez, X., D’agosto, M., Dimitriu, D., Figueroa Meza, M., Fulton, L., Kobayashi, S., and Lah, O.: Transport, Cambridge University Press, Cambridge, UK and New York, USA, 2014.

Sopper, W. E. and Lull, H. W.: The representativeness of small forested experimental watersheds in northeastern United States, International Association of Hydrological Sciences, 66, 441456, 1965.

Stamboliadis, E., Pantelaki, O., and Petrakis, E.: Surface area production during grinding, Miner. Eng., 22, 587-592, 2009.

Strefler, J., Amann, T., Bauer, N., Kriegler, E., and Hartmann, J.: Potential and costs of carbon dioxide removal by enhanced weathering of rocks, Environ. Res. Lett., 13, 034010, https://doi.org/10.1088/1748-9326/aaa9c4, 2018.

Tans, P. and Keeling, R.: Mauna Loa $\mathrm{CO}_{2}$ monthly mean data, United States National Oceanic and Atmospheric Administration, Global Monitoring Laboratory, available at: https://www. esrl.noaa.gov/gmd/ccgg/trends/data.html (last access: 15 April 2020), 2017.

Teien, H.-C., Kroglund, F., Åtland, Å., Rosseland, B. O., and Salbu, B.: Sodium silicate as alternative to liming-reduced aluminium toxicity for Atlantic salmon (Salmo salar L.) in unstable mixing zones, Sci. Total Environ., 358, 151-163, 2006.

The Royal Society and the Royal Academy of Engineering: Greenhouse gas removal, 134 pp., available at: https://royalsociety. org/topics-policy/projects/greenhouse-gas-removal (last access: 24 April 2019), 2018.

Traaen, T., Frogner, T., Hindar, A., Kleiven, E., Lande, A., and Wright, R.: Whole-catchment liming at Tjønnstrond, Norway: an 11-year record, Water, Air Soil Poll., 94, 163-180, 1997.

United States Environmental Protection Agency: Emissions \& Generation Resource Integrated Database (eGRID), available at: https://www.epa.gov/sites/production/files/2018-02/egrid2016_ all_files_since_1996.zip (last access: 16 September 2019), 1999.

Virta, R. L.: Minerals Yearbook: Wollastonite, available at: https://www.usgs.gov/centers/nmic/ wollastonite-statistics-and-information (last access: 21 June 2019), 2000.

Zhao, Y., Duan, L., Xing, J., Larssen, T., Nielsen, C. P., and Hao, J.: Soil acidification in China: is controlling $\mathrm{SO}_{2}$ emissions enough?, Environ. Sci. Technol., 43, 8021-8026, https://doi.org/10.1021/es901430n, 2009. 